\title{
A Review of Solar Photovoltaic Concentrators
}

\author{
Mehrdad Khamooshi, ${ }^{1}$ Hana Salati, ${ }^{1}$ Fuat Egelioglu, ${ }^{1}$ Ali Hooshyar Faghiri, ${ }^{1}$ \\ Judy Tarabishi, ${ }^{1}$ and Saeed Babadi ${ }^{2}$ \\ ${ }^{1}$ Department of Mechanical Engineering, Faculty of Engineering, Eastern Mediterranean University, Famagusta, \\ North Cyprus, Via Mersin 10, Turkey \\ ${ }^{2}$ Department of Electrical and Computer Engineering, University of Concordia, Montreal, QC, Canada H4B 1 R6
}

Correspondence should be addressed to Mehrdad Khamooshi; mehrdadkhamooshi@yahoo.com

Received 5 March 2014; Revised 12 April 2014; Accepted 26 April 2014; Published 19 June 2014

Academic Editor: Dimitrios Karamanis

Copyright ( $) 2014$ Mehrdad Khamooshi et al. This is an open access article distributed under the Creative Commons Attribution License, which permits unrestricted use, distribution, and reproduction in any medium, provided the original work is properly cited.

\begin{abstract}
Throughout the recent centuries, the limits of using energy resources due to the cost and environmental issues became one of the scientists' concerns. Because of the huge amount of energy received by the Earth from the sun, the application of photovoltaic solar cells has become popular in the world. The photovoltaic (PV) efficiency can be increased by several factors; concentrating photovoltaic (CPV) system is one of the important tools for efficiency improvement and enables for a reduction in the cell area requirement. The limits of the PV area can reduce the amount of absorbing irradiation; CPV systems can concentrate a large amount of sunlight into a smaller one by applying lenses or curved and flat mirrors. However, the additional costs on concentrating optics and cooling systems made CPV less common than nonconcentrated photovoltaic. This paper reviews the different types of PV concentrators, their performance with advantages and disadvantages, concentration ratio, acceptance angle, brief comparison between their efficiencies, and appropriate cooling system.
\end{abstract}

\section{Introduction}

As the fossil fuels are reducing gradually in our planet, solar photovoltaic systems and technology are becoming a promising option for electricity generation. The amount of solar power output is about $166 \mathrm{PW}$ out of which $85 \mathrm{PW}$ reaches the Earth. This shows not only that solar power is well over 500 times our current world $15 \mathrm{TW}$ power consumption, but also that all other sources are less than $1 \%$ of solar power output [1-3]. The radiation, that is, not reflected or scattered and reaches the surface directly is called direct or beam radiation and the scattered radiation reaching the ground is called diffuse radiation [4]. Basically, the role of concentration photovoltaic systems is to collect both beam and scattered irradiation, which do not reach the photovoltaic cells. Besides photovoltaic, the concentrator also has other applications such as thermal power applications [5-7], lighting systems [8-10], pumping of solar lasers [11-15], hydrogen production [16-18], and other applications. Although Parida et al. [19] performed a fundamental review study on the solar photovoltaic technologies and McConnell et al. [20] reviewed market aspects of solar concentrators, there is no complete review on concentrated photovoltaic technologies. The aim of this study is therefore to review different CPV technologies and their other characteristics such as performance, advantages, disadvantages, and appropriate cooling system.

\section{Solar Concentrators}

In a simple description, the idea of CPV is using optical devices with cheap and suitable technology to concentrate the light on small and highly efficient photovoltaic solar cells. Hence, the cost will be reduced by means of replacing the cell surface with cheaper optical devices [21]. There are some advantages and disadvantages solar concentrator systems have over flat plate systems for large installations. Table 1 obtained from the [22] shows some advantages of CPV.

Solar concentrators are classified by their optical characteristics such as the concentration factor, distribution of illumination, focal shape, and optical standard. Concentration 
TABLE 1: Advantages of concentrating over flat-plate systems for large PV installations [22].

GaAs dish concentrators are projected to produce electricity at 7.4 cents/kWh by 2010, whereas thin-film modules are projected to be at 9.6 cents $/ \mathrm{kWh}$. If thin-film module prices come down from the assumed $\$ 75 / \mathrm{m}^{2}$ to $\$ 35 / \mathrm{m}^{2}$ at $12 \%$ efficiency (29 cents/W), then thin-film electricity cost would equal GaAs dish cost.

Lower cost Concentrators are the only option to have system efficiencies over $20 \%$. This reduces land utilization as well as area related costs.

Superior efficiency Tracking provides for improved energy output. Once the expense of tracking is

Higher annual capacity factor incurred with flat-plates, the leap to installing concentrator modules is small.

Concentrators use standard construction materials for the bulk of their

Less materials availability issues requirements. Flat-plate systems have serious concerns over material availability: silicon feedstock, or indium in the case of CuInSe2.

Less toxic material use Many thin-film concepts use quite toxic materials such as cadmium, and so forth. The trend in modern mass-product manufacturing is to make a product as recyclable as possible.

Ease of recycling Concentrators are composed mainly of easily recyclable materials, steel, aluminum, and plastic.

Recycling flat-plate modules will be much more difficult.

Existing semiconductor manufacturing capacity is more than sufficient to supply projected cell requirements. The remaining manufacturing is comprised of rather standard mechanical components.

Ease of rapid manufacturing capacity scale-up This greatly reduces capital requirements compared to flat-plate.

High local manufacturing content Aside from the cells, the remaining content of concentrator systems can be manufactured worldwide, and close to the final point-of-use.

factor $X$, which is also known as the number of suns, is the ratio of the mean radiant flux density on a receiver area $G_{x}$ compared to the average normal global irradiance $G[23]$ :

$$
X=\frac{G_{x}}{G} .
$$

The classification based on the concentration factor includes the following conditions [24]:

(i) low concentration (LCPV): (1-40x),

(ii) medium concentration (MCPV): (40-300x),

(iii) high concentration (HCPV): (300-2000x).

Also the efficiencies of different PV cells can be obtained from the following [25]:

$$
\eta=\frac{P_{\max }}{\mathrm{ArEe}}
$$

where $\eta$ is efficiency, $P_{\max }$ is the ratio of the optimal electric power delivered by the PV cell, Ar is the area of the PV cell exposed to sunlight, and solar irradiance received by the PV is Ee.

Higher tracker tolerances, passive heat sinks, lower cost optics, reduced manufacturing costs, and reduced installation precision made LCPV more simple compared to HCPV [26]. The experimental findings by Butler et al. [27] show that LCPV has the potential to harvest more energy when using standard Si solar cells in a basic concentration configuration as used in this study. However, Pérez-Higueras et al. [24] stated that high concentrator photovoltaic technology is still in a deployment stage, but the cells and modules efficiency data offered by their manufacturing companies, as well as the measuring experiments carried out by several research centers, forecast an attractive short-term increment in their efficiency, which means that these systems could be profitable in economical and energy terms in a short period of time. This fact represents a potential alternative to flat module photovoltaic systems in the energy generation market.

Based on the Pérez-Higueras et al. study [24], Table 2 shows different HCPV efficiencies in the laboratories and in commercials.

They are also classified in two other optical categories: (1) imaging optical concentrators, which means the image formed on the receiver by the optical concentrators [28] and (2) nonimaging optical concentrators: the receiver is not concerned with forming an image on it by optical concentrators [29].

2.1. Overview on Different Models. During past decades, a lot of developments have been made on designing different models of solar concentrators. Experts analyzed these models through these decades and there have been some changes in their design. This part presents different models of concentrators.

2.1.1. Fresnel Lenses. Fresnel lenses recently have been one of the best choices due to their noble properties such as small volume, light weight, as well as mass production with low cost [30]. In early Fresnel lenses, glass was replaced by polymethylmethacrylate (PMMA), discovered by Augustin Jean Fresnel, with optical characteristics almost the same as glass including good transmissivity and resistance to sunlight; it is the suitable material choice for the manufacturing of Fresnel lenses [31, 32]. A Fresnel lens is a flat optical 
TABLE 2: Different HCPV efficiencies recorded in Laboratories and commercials [24].

\begin{tabular}{|c|c|c|c|c|}
\hline & Efficiency (\%) & Suns & Type & Description \\
\hline \multicolumn{5}{|c|}{ Laboratories efficiencies } \\
\hline 1 & 41.6 & 364 & GaInP/GaInAs/Ge & Lattice-matched \\
\hline 2 & 41.1 & 454 & $\mathrm{GaInP} / \mathrm{GaInAs} / \mathrm{Ge}$ & Lattice-mismatched \\
\hline 3 & 40.8 & 326 & GaInP/GaInAs/GaInAs & Inverted monolithic \\
\hline 4 & 40.7 & 240 & GaInP/GaInAs/Ge & Lattice-mismatched \\
\hline 5 & 37.2 & 500 & $\mathrm{nGaP} / \mathrm{InGaAs} / \mathrm{Ge}$ & Lattice-matched \\
\hline \multicolumn{5}{|c|}{ Commercials efficiencies } \\
\hline 1 & 39 & 500 & Multijunction & http://www.emcore.com \\
\hline 2 & 38.5 & 500 & Multijunction & http://www.spectrolab.com \\
\hline 3 & 35 & 500 & Multijunction & http://www.spirecorp.com \\
\hline 4 & 35 & 300 & Multijunction & http://www.azurspace.com \\
\hline 5 & 27 & 100 & Silicon & http://www.amonix.com \\
\hline
\end{tabular}

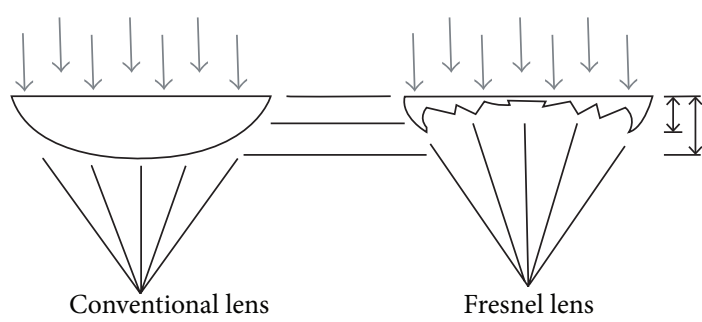

Figure 1: Conventional lens and Fresnel lens [30].

component where the bulk material is eliminated because the surface is made up of many small concentric grooves. These grooves individually act as prisms since each groove is approximated by a flat surface that reflects the curvature at that position of the conventional lens [33]. Figure 1 shows the schematic view of conventional lens and Fresnel lens.

The concentration of flux is represented as follows [34]:

$$
C_{\max }=\frac{n^{2}}{\sin \theta \sin \psi}
$$

where $C_{\max }$ represents the maximum concentration of optical flux (unitless); $n$ is the real component of the refractive index (unitless); and $\theta$ (acceptance angle along the plane of the azimuth) and $\psi$ (the acceptance angle of the altitude) are the acceptance angles.

Briefly, concentrated solar energy applications using Fresnel lens systems are in following categories: thermal application, thermal heating, solar cooking $[5,35,36]$, photocatalytic [37], solar building [38], solar-pumped laser [39-41], lighting $[42,43]$, and surface modification of metallic materials [33, 44-46].

There are two main types of Fresnel lenses which are circular and linear. For the circular category, Nakata et al. [47] described a $300 \mathrm{~W}$ polar axis tracking concentrator with 36 circular Fresnel lenses $(40 \times 40)$ and designed cells to obtain the uniform distribution. As a result, the optical efficiency of the lens is $83 \%$ and the output power becomes about $50 \%$ greater than that of the commercial lens, an experimental and analytical method used by Harmon [48] to determine the efficiency and intensity variations of a circular Fresnel lens as a solar concentrator. Using a photovoltaic scanning technique, the experimental part and simulation are constructed to model the behavior of the lens. According to the results, the lens is an inefficient concentrator with losses that begin at $20 \%$ and rise to about $80 \%$ as the focal distance decreases.

A research done by Whitfield et al. [49] compares Pointfocus Fresnel lens, two-axis tracking, and the use of the housing as heat Sink with other models which include linear Fresnel lens, solid CPC secondary's, and two-axis tracking. Linear Fresnel lens system has the advantage of being simple and totally enclosed yet is more costly than some of the others. The point-focus Fresnel lens has the advantage of having potential for simple mass-produced optics but its serious problem is the loss of efficiency at higher concentration. Optical properties of flat linear Fresnel lenses manufactured from glass are presented by Franc et al. [50] and the behavior of these lenses in perpendicular and inclined beams of rays is discussed.

2.1.2. Quantum Dot Concentrator. Quantum dot concentrator (QDC) is a nontracking concentrator that includes three main parts; transparent flat sheet of glass or plastic doped with quantum dots (QDs), reflective mirrors placed on three different edges and the back surface, and a PV cell which is attached to the exit aperture. As it is shown in Figure 2 when the sun radiation hits the surface of concentrator, a part of the radiation will be refracted by a fluorescent material and absorbed by quantum dots (QDs); photons are reemitted isotropically at a lower frequency and guided to the PV cell [25]. The size of quantum dots, which are made of nanostructures, typically varies from tens to hundreds of nanometers in size [51].

Research done by Mićić et al. [52] has shown that QDs are capable of absorbing light over an extremely broad wavelength range and the absorption spectra also depicts the spectral shift to higher energy as QD size decreases. The main advantages of QDC are the following: they are without any tracking system, they can concentrate both diffuse and direct radiations [53], due to the geometries of these 


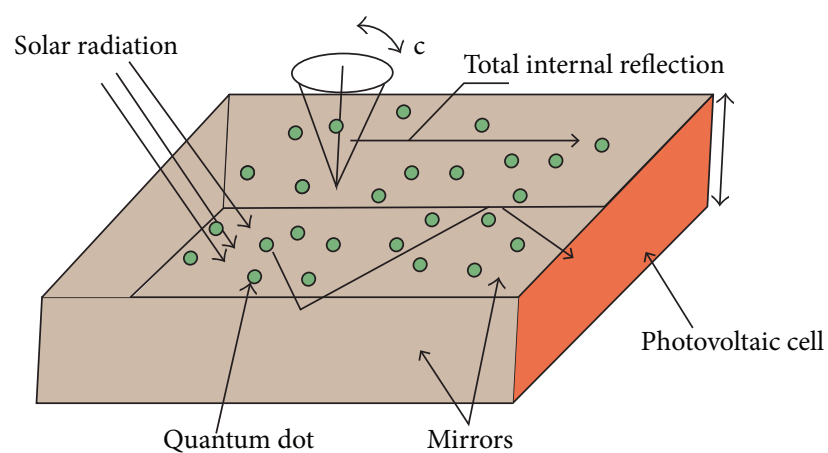

Figure 2: Principle of the QDC [25].

concentrators, they have less problems of heat dissipation [25], and sheets are inexpensive and are suitable architectural components [54]. Developing QDCs was restricted by the stringent requirements of the luminescent dyes such as high quantum efficiency, suitable absorption spectra and red shifts, and illumination stability $[55,56]$. The problems of organic dyes can settle by replacing them with QDs which have the advantages of less degradation and high luminescence [57]. Schüler et al. [58] proposed that quantum dot containing nanocomposite coatings might be an alternative for the production of planar quantum dot solar concentrators. The concentration ratios of QDCs are completely discussed by Gallagher et al. [25] who determined concentration ratios of different types by comparative analysis. A maximum comparative concentrating factor (MCCF) was determined at specific solar intensities using (4):

$$
\mathrm{MCCF}=\frac{P_{\text {dev-max }}}{P_{\text {max }- \text { ref }}},
$$

where $P_{\text {dev-max }}$ is the power maximum for the test device and $P_{\text {ref-max }}$ is the power maximum for the reference devices.

2.1.3. Parabolic Concentrator. The solar parabolic trough collector is the most recognized technology due to its high dispatchability and low unit cost. In parabolic trough concentrators, the parabolic shaped mirror focuses sunlight on the receiver tube which is placed at the focal point of parabola [59]. Reflectivity of the mirror, incident angle, tracking error, intercept factor, as well as absorptivity of the receiver, are the factors which can affect the performance of the parabolic trough concentrator [60]. Additionally, Riffelmann et al. [61] mentioned the image quality of the mirror, slope error, and collector assembly, as the factors which the optical efficiency of a parabolic trough collector depends on.

In order to enhance the concentration efficiency of the parabolic trough, Omer and Infield [62] discussed the twostage concentration of the parabolic trough collector. This design provides an efficient concentration of the incident solar radiation without any frequent tracking system. The performance of the parabolic trough collector depends on receiver design and heat loss from the receiver [60, 63-68]. The heat loss can increase by different tools; one of them is inserting porous inserts in the inner surface of the receiver.
The porous inserts increase the heat transfer rate by (1) increasing the effective fluid thermal conductivity, (2) enhancing mixing between the fluid and receiver wall, and (3) lowering thermal resistance by developing a thinner hydrodynamic boundary layer [59]. Figure 3 shows a schematic view of a parabola.

The concentration ratio of the Parabolic concentrator can be obtained from $(5)[69,70]$ :

$$
\begin{gathered}
\mathbf{C}=\frac{\sin \phi_{R}}{\pi \sin \theta_{\alpha}} \\
\tan \left(\frac{\phi_{R}}{2}\right)=\frac{2 y_{s}}{4 f}=\frac{y_{s}}{2 f},
\end{gathered}
$$

where $\theta_{\alpha}$ is half the acceptance angle, $\phi_{R}$ is the rim angle, and $f$ is focus length.

2.1.4. Compound Parabolic Concentrator (CPC). Compound parabolic concentrators (CPCs) are designed to efficiently collect and concentrate distant light sources with some acceptance angle. Figure 4 illustrates the configuration of CPC.

The geometrical concentration ratio and theoretical maximum possible concentration ratio of the $\mathrm{CPC}$ are obtainable from $(6)[71,72]$ :

$$
\begin{gathered}
\mathrm{CR}=\frac{A_{a}}{A_{r}} \\
\mathrm{CR}_{\max , 3 \mathrm{D}}=\frac{1}{\sin ^{2}(1 / 2) \theta_{\max }},
\end{gathered}
$$

where $A_{a}, A_{r}$, and $\theta_{\max }$ are the aperture area, receiver area, and maximum acceptance angle, respectively.

CPCs can be in both 2-dimensional and 3-dimensional configuration. Suzuki and Kobayashi's [73] study on 2-D CPC is about the optimum acceptance angle of the concentrator with the declination angle of \pm 23.5 on the celestial hemisphere for direct radiation and uniform irradiance for diffuse radiation. The results indicate that the optimum halfacceptance angle is 26 degrees irrespective of the change in the diffuse radiation fraction. It was also found that almost all over the Earth, a common CPC is an optimum application for many solar collecting systems.

Senthilkumar et al. [74] performed substantial research work in order to improve the performance of the twodimensional compound parabolic concentrator (2D CPC). They found out that the three-dimensional compound parabolic concentrator (3D CPC) is more efficient than the 2D CPC because of the higher concentration ratio. Yehezkel et al. [75] analyzed the losses due to reflection properties and calculated the effect of these losses on concentration ratio. They estimated reflection losses using an empirical linear model to facilitate design and system optimization by analytical methods without resorting to a ray-tracing procedure.

Khalifa and Al-Mutawalli [76] did an experimental study on effects of two-axis sun tracking on thermal performance of CPC in two different modes; in the first, a batch feeding 


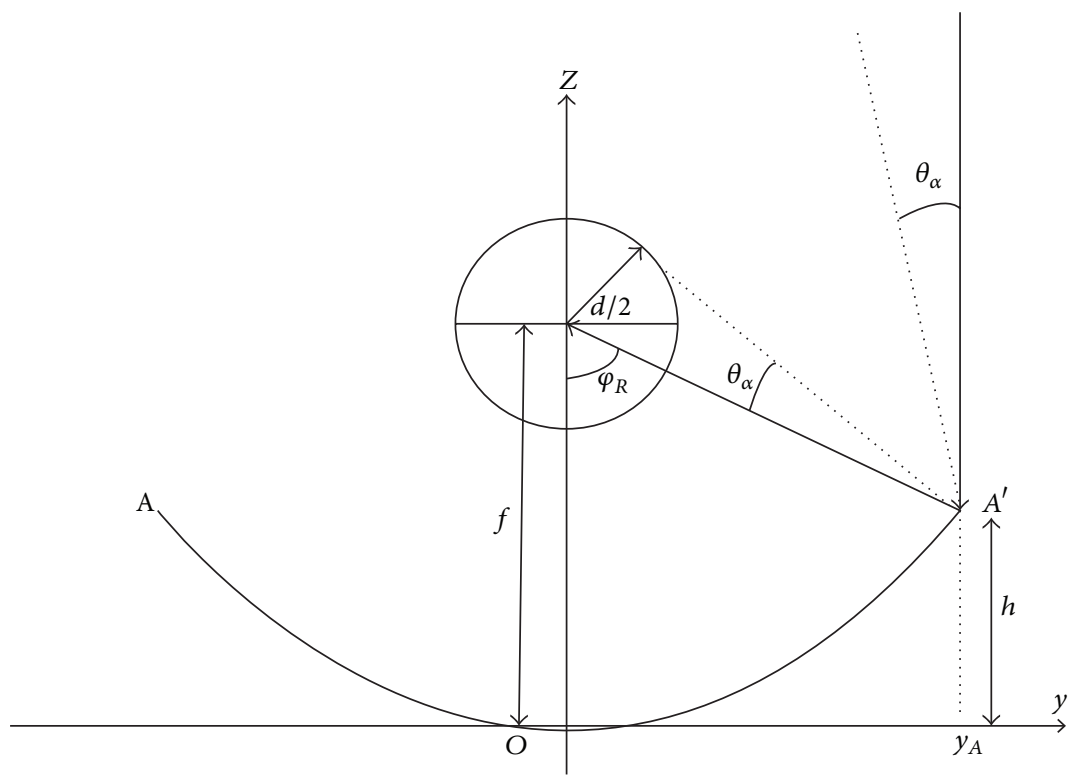

Figure 3: Schematic view of the parabola.

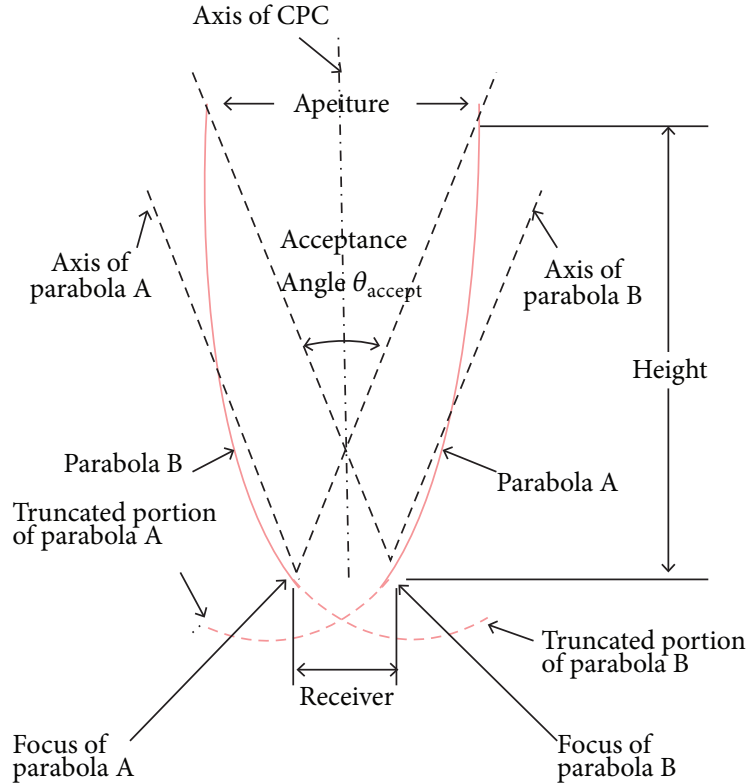

FIGURE 4: Cross section of a nontruncated CPC [132].

was used where no flow through the collector was allowed whereas in the second, different steady water flow rates were used. The results led us to the conclusion that the energy gain of a CPC collector can be increased by using two-axis tracking systems. The best improvement was achieved when the flow rate was in the range of 25 to $45 \mathrm{~kg} / \mathrm{hr}$.

Mallick et al. [77] designed a novel nonimaging asymmetric compound parabolic photovoltaic concentrator (ACPPVC) with different numbers of PV strings connected in series experimentally characterized under outdoor conditions both with and without concentrators which indicated that the use of an ACPPVC increased the maximum power point by $62 \%$ when compared to a similar nonconcentrating PV panel.

2.1.5. Dielectric Totally Internally Reflecting Concentrator (DTIRC). Dielectric totally internally reflecting concentrator (DTIRC) which was suggested by Ning et al. [78] is one of the most important nonimaging optical concentrators. In addition to the solar application, these lenses were proposed for IR detection [79] and optical wireless communication systems [80, 81].

As shown in Figure 5, DITRCs consist of three main parts: a curved front surface, a totally internally reflecting profile, and an exit aperture [81].

The important factor for rays to reach the exit aperture is to be within the designed acceptance angle of the concentrator. When a set of rays hits the front curved surface at the acceptance angle, it is refracted and directed to the exit aperture. Ning et al. [82] discussed two-stage photovoltaic concentrators with Fresnel lenses as primaries and dielectric totally internally reflecting nonimaging concentrators as secondaries. The results indicated that two-stage concentrator suggests higher concentration and more uniform flux distribution on the photovoltaic cell than the point focusing Fresnel lens alone. Muhammad-Sukki et al. [83] described designing a dielectric totally internally reflecting concentrator (DTIRC). They used maximum concentration method (MCM) which was outlined with the simulation to optimize the design of the concentrator. The results from MATLAB simulations indicate that MCM offers a higher geometrical concentration gain, with a slight increase in the concentrator size.

The advantages of DTIRC over compound parabolic concentrator are higher efficiency, higher concentration ratio, flux tailoring, and work without any needs of cooling features. However, DTIRC itself cannot efficiently pass all of 


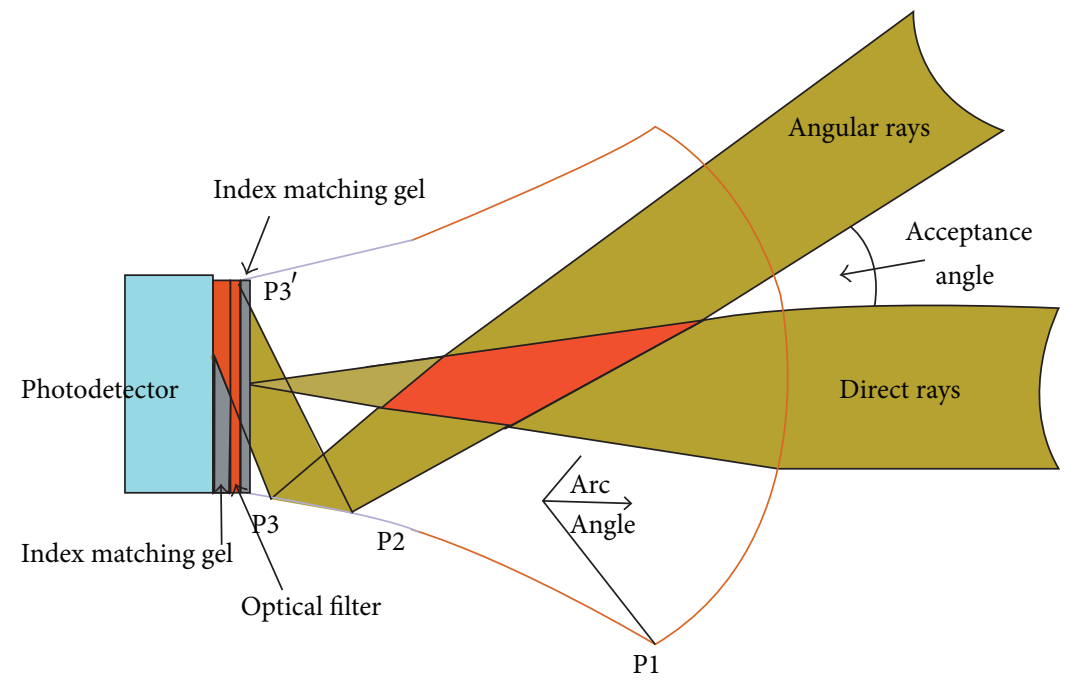

FIgURE 5: Side view of a DTIRC [81].

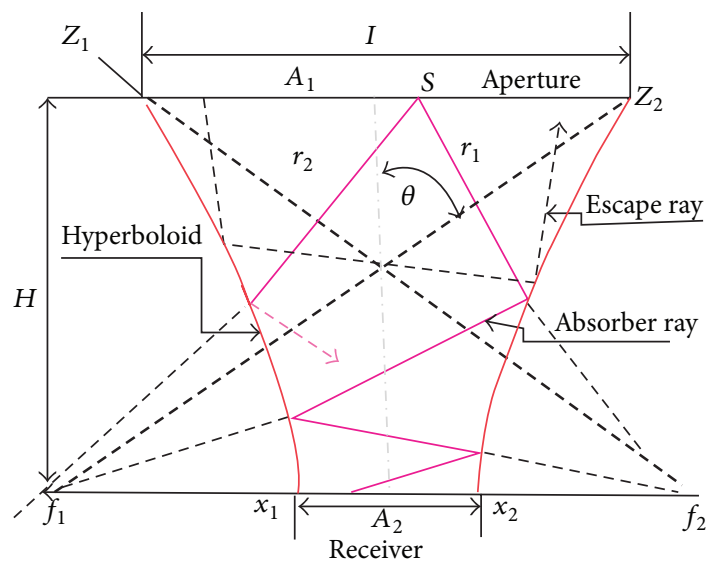

FIGURE 6: 2-D Hyperboloid concentrator [86].

the solar energy that it accepts into a lower index media [84]. Muhammad-Sukki et al. [85] present a study about a mirror symmetrical dielectric totally internally reflecting concentrator (MSDTIRC) which is a new type of DTIRC. They presented a method for calculating concentration gain of the mentioned system.

2.1.6. Hyperboloid Concentrator. Figure 6 shows two dimensional hyperboloid concentrators. Incident rays on the aperture enter the hyperboloid concentrator and either reach the receiver or reflect back out of the concentrator [86]. This kind of concentrator is also called the elliptical hyperboloid concentrator. A 3-D figure of an elliptical hyperboloid concentrator is showed in Figure 7.

The advantage of this concentrator is that it is very compact, since only a truncated version of the concentrator needs to be used. Because of this factor, it is mainly used as a secondary concentrator [87]. Garcia-Botella et al. [29] found out that the one-sheet hyperbolic concentrator is an ideal 3D

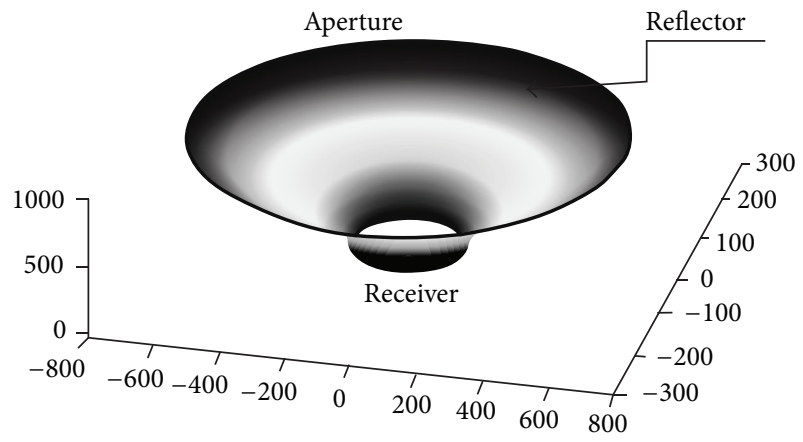

FiguRE 7: 3-D elliptical hyperboloid concentrator.

asymmetric concentrator as its shape does not disturb the flow lines of an elliptical disk. It also does not need a tracking system where two different acceptance angles, transversal and longitudinal direction, are needed.

Sellami et al. [88] designed a 3-D concentrator and coined the Square elliptical hyperboloid $(\mathrm{SEH})$ to be integrated in either glazing windows or facades for photovoltaic application. This configuration can collect both diffuse and direct beam. They also found that optical efficiency depends on the size of the SHE.

It has been shown that the 3-D solar concentrator acquired from the hyperboloid has the ability of concentrating all the entering rays [89] such as the trumpet concentrator, which is composed of a revolution of hyperbolic type and was considered as an ideal concentrator [90].

Chen et al. [91] investigated a solar concentrator containing primary paraboloidal and secondary hyperboloidal mirrors by using the ray tracing method to obtain higher concentration ratio. The results indicated that such a method can increase the concentration of solar flux twice when concentration tracking errors exist.

Saleh Ali et al. [92] presented a study about designing a static 3-D solar elliptical hyperboloid concentrator (EHC). 


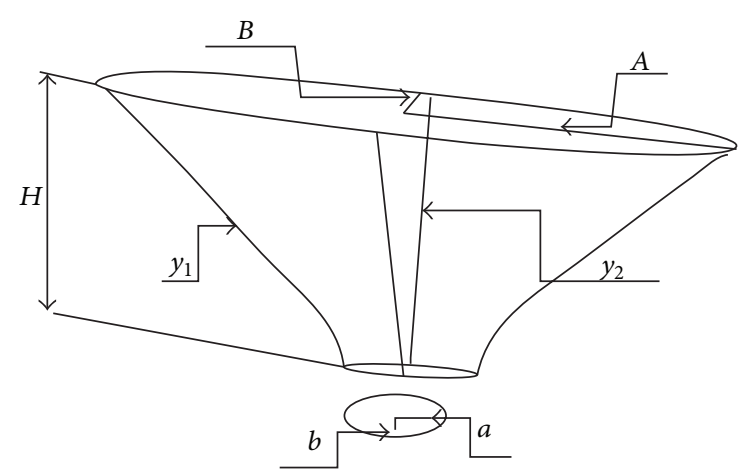

FIGURE 8: Geometrical parameters of an elliptical hyperboloid concentrator [92].

They proposed some equation for designing hyperboloid concentrators [92], based on Figure 8.

The design of hyperboloid concentrators is based on the following equations:

$$
\begin{gathered}
\frac{x^{2}}{a^{2}}+\frac{y^{2}}{b^{2}}-\frac{z^{2}}{c^{2}}=1, \\
y_{1}=\left[\left\{\left(\frac{x^{2}}{a^{2}}\right)-1\right\} \times\left\{H^{2} \times(\mathrm{CR}-1)\right\}\right]^{0.5}, \\
y_{2}=\left[\left\{\left(\frac{x^{2}}{b^{2}}\right)-1\right\} \times\left\{H^{2} \times(\mathrm{CR}-1)\right\}\right]^{0.5}, \\
B=\left(\mathrm{CR} \times(b)^{2}\right)^{0.5}, \\
\mathrm{CR}=\frac{A_{p}}{A_{r}} .
\end{gathered}
$$

2.1.7. $R R, X X, X R, R X$, and $R X I$. These configurations represent the new concentrators which achieved the theoretical maximum acceptance angle concentration and it was concluded that they may be useful for high concentration cells [93].

In these designs " $R$ " denotes refraction, " $\mathrm{X}$ " denotes reflection, and "I" denotes internal reflection [94]. The design methods of all these concentrators are basically similar to each other. RXI designs can almost describe other models as shown in Figure 9; rays that impinge on the concentrator aperture, within the acceptance angle, are directed to the receiver by means of one refraction, one reflection, and one total internal reflection [95].

Minano et al. [96] investigated the performance of RX and the results indicated that when the angular spread of the input bundle is small, the performance of the rotational RX is acceptable. An analysis of the RX concentrator performed by Benitez and Minano [97] stated that when the field of view is small (less than 6 degrees full angle), even for concentrations up to $95 \%$ of the theoretical maximum, its imaging performance is similar (in MTF terms) to that of normal incidence of an $f / 3.7$ planoconvex spherical lens with optimum defocusing. This image capability is suitable for receivers. Minano et al. [98] explored a research for RX and RXI concentrators. Their results had shown that when the acceptance angle of the concentrator is less than 5 degrees (for a source at infinity), its performance in $3 \mathrm{D}$ is very good. Also, the RX shown in their analysis had been designed for a finite source and the RXI for a source at infinity.

\section{Tables of Properties}

Table 3 shows the advantages and disadvantages of the different types of solar concentrators.

Based on Peterina et al.s [99] study Table 4 represents different kinds of CPV modules and their typical size and power.

Swanson [22] performed a review study on the characteristics of concentrated photovoltaic systems which approached the economical aspects of the systems. Table 5 summarized Swanson's study which represents different CPV with their characteristics.

For the cost comparison of different CPV systems Table 6 which is obtained from Whitfield et al. [49] presents some $\mathrm{CPV}$ systems with their cost.

\section{Appropriate Cooling Systems}

Cooling of photovoltaic cells under concentrated illumination is one of the major problems during designing them. The photovoltaic cell efficiency decreases with increasing temperature or due to nonuniform temperature [100-109]. Also, cell degradation will occur if the temperature exceeds certain limits [102].

The thermal properties of the coolant are another important factor for choosing the right cooling system. Thermal properties of air make it less efficient compared to water which results in more parasitic power [110]. Also, the coolant or working fluid should be compatible, which means that it should not attack or corrode the envelope or wick and there is no chemical reaction between the working fluid and the envelope or wick structure that liberates noncondensable gas (NCG) [111].

Heat pipes are popular and interesting technology with the aim of cooling the PV modules especially under concentration. A heat pipe is a vacuum tight device consisting of a working fluid and a wick structure [111]. The working fluid transfers the additional and the rejected heat by condensation processes. Heat pipes are usually made of aluminum or copper; Table 7 shows the compatible working fluid for copper and aluminum based on refs. [111-113].

Akbarzadeh and Wadowski [114] made reports on a parabola-trough that uses heat pipes for cooling. Each cell is mounted vertically on the end of a thermosyphon which is made of a flattened copper pipe with a finned condenser area. The cell temperature does not go beyond $46^{\circ} \mathrm{C}$ on sunny days with the concentration ratio of 20 suns; the reports show that 


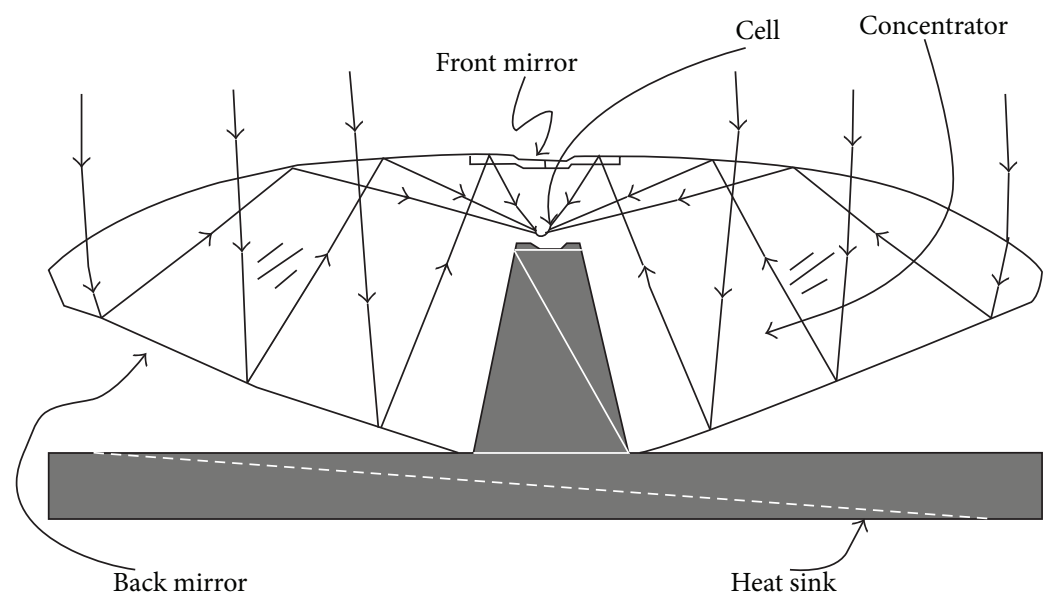

FIgURE 9: RXI concentrator cross-section [93].

TABLE 3: Advantages and disadvantages of solar concentrators.

\begin{tabular}{|c|c|c|c|c|}
\hline $\begin{array}{l}\text { Type of } \\
\text { concentrator }\end{array}$ & Advantages & Reference & Disadvantages & Reference \\
\hline Fresnel lens & $\begin{array}{l}\text { (i) Small volume } \\
\text { (ii) Light weight } \\
\text { (iii) Mass production }\end{array}$ & {$[30]$} & $\begin{array}{l}\text { (i) Imperfection on the edges of the facets, } \\
\text { causing the rays to be improperly focused at } \\
\text { the receiver } \\
\text { (ii) Possibility of lost light due to incidence on } \\
\text { the draft facet } \\
\text { (iii) Luminance is necessarily reduced in order } \\
\text { to minimize the upper disadvantages }\end{array}$ & {$[133,134]$} \\
\hline $\begin{array}{l}\text { Quantum dot } \\
\text { concentrator }\end{array}$ & $\begin{array}{l}\text { (i) Nontracking concentrator } \\
\text { (ii) Have less problems of heat dissipation } \\
\text { (iii) Sheets are inexpensive and are suitable } \\
\text { architectural components }\end{array}$ & {$[25,54]$} & $\begin{array}{l}\text { Developing QDCs was restricted by stringent } \\
\text { requirements of the luminescent dyes }\end{array}$ & {$[55,56]$} \\
\hline Parabolic trough & Make efficient use of direct solar radiation & {$[135]$} & $\begin{array}{l}\text { (i) Use only direct radiation } \\
\text { (ii) high cost } \\
\text { (iii) low optical and quantum efficiencies }\end{array}$ & {$[135]$} \\
\hline $\begin{array}{l}\text { Compound } \\
\text { parabolic } \\
\text { concentrator }\end{array}$ & $\begin{array}{l}\text { Most of radiation within the acceptance angle } \\
\text { can transmit trough the output aperture into } \\
\text { receivers }\end{array}$ & {$[136]$} & $\begin{array}{l}\text { Needs good tracking system in order to get } \\
\text { maximum efficiency }\end{array}$ & {$[137]$} \\
\hline $\begin{array}{l}\text { Dielectric totally } \\
\text { internally } \\
\text { reflecting } \\
\text { concentrator }\end{array}$ & $\begin{array}{l}\text { (i) Higher efficiency and concentration ratio } \\
\text { than CPC } \\
\text { (ii) Work without any needs of cooling features }\end{array}$ & {$[84]$} & $\begin{array}{l}\text { Cannot efficiently pass all of the solar energy } \\
\text { that it accepts into a lower index media }\end{array}$ & {$[84]$} \\
\hline $\begin{array}{l}\text { Hyperboloid } \\
\text { concentrator }\end{array}$ & Very compact & {$[87]$} & $\begin{array}{l}\text { Need to introduce lens at the entrance aperture } \\
\text { to work effectively }\end{array}$ & {$[87]$} \\
\hline $\begin{array}{l}\mathrm{RR}, \mathrm{XX}, \mathrm{XR}, \mathrm{RX} \text {, } \\
\text { and RXI }\end{array}$ & $\begin{array}{l}\text { (i) Achieving the theoretical maximum } \\
\text { acceptance angle concentration } \\
\text { (ii) High concentration } \\
\text { (iii) Lighter weight } \\
\text { (iv) Less expensive tracking system }\end{array}$ & {$[93,138]$} & $\begin{array}{l}\text { The size of the cell must be kept to minimum to } \\
\text { reduce shadowing effect }\end{array}$ & {$[138]$} \\
\hline
\end{tabular}

the temperature will pass $84^{\circ} \mathrm{C}$ without fluid in the cooling system.

Horne presents a cooling system for a paraboloidal dish which focuses the light onto cells [115]. Water is sent to the receiver by a central pipe. It then flows behind the cells. By applying this method, not only does the water cool the cells, but it also acts as a filter by absorbing a significant amount of UV radiation that would otherwise reach the cells. Russell patented a heat pipe cooling system for linear Fresnel lenses in which each of them focuses the light onto a string of cells placed along the length of a heat pipe of circular cross-section; the panel is formed by several pipes mounted next to each other [116] (Figure 10).

Thermal energy is extracted from the heat pipe by an internal coolant circuit where inlet and outlet are on the same pipe end ensuring a uniform temperature along the pipe. 
TABLE 4: Description of CPV modules.

\begin{tabular}{|c|c|c|c|c|c|c|c|}
\hline CPV Type & Optics & Cell type & C. Ratio & Cooling & Tracking & Size & Power \\
\hline Point focus & Fresnel & $\begin{array}{c}\text { Silicon } \\
\text { III_V }\end{array}$ & $50<x<500$ & Passive & Two axis & $215 \mathrm{~m}^{2}$ & $25 \mathrm{~kW}$ \\
\hline $\begin{array}{l}\text { Large area point } \\
\text { focus }\end{array}$ & $\begin{array}{l}\text { Parabolic dish central } \\
\text { tower }\end{array}$ & $\begin{array}{l}\text { Silicon } \\
\text { III_V }\end{array}$ & $150<x<500$ & Active & Two_axis & $14 \mathrm{~m}$ diameter, $135 \mathrm{~m}^{2}$ & $24 \mathrm{~kW}$ \\
\hline Linear system & $\begin{array}{l}\text { Linear lens parabolic } \\
\text { trough }\end{array}$ & $\begin{array}{l}\text { Silicon } \\
\text { III_V }\end{array}$ & $\begin{array}{l}15<x<60 \\
60<x<300\end{array}$ & Passive & $\begin{array}{c}\text { One axis on } \\
\text { parabolic }\end{array}$ & $\begin{array}{l}84 \text { meter long and } \\
250 \mathrm{~m}^{2} \text { aperture }\end{array}$ & $34 \mathrm{~kW}$ \\
\hline Static systems & Non imaging device & Silicon & $1.5<x<10$ & Passive & No tracking & - & - \\
\hline Mini point focus & $\begin{array}{l}\text { Small lens RXI device } \\
\text { small parabolic }\end{array}$ & $\begin{array}{l}\text { Silicon } \\
\text { III_V }\end{array}$ & $300<x<1000$ & Passive & Two_axis & $2 \mathrm{~m}^{2}$ & $200 \mathrm{~W}$ \\
\hline
\end{tabular}

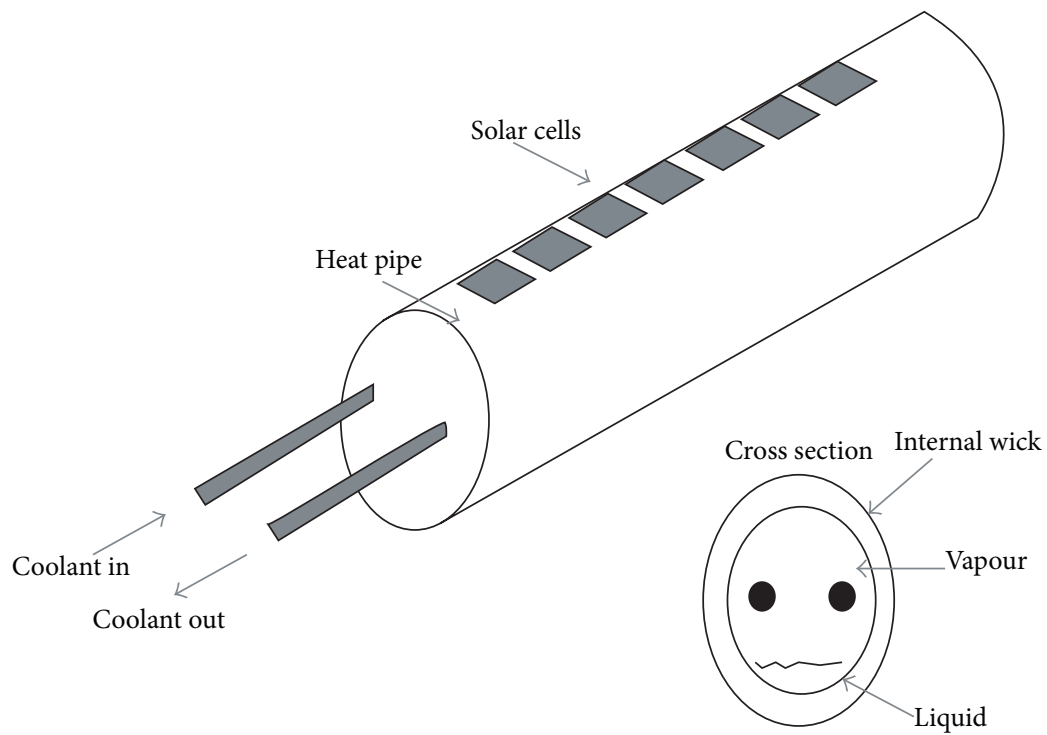

FIGURE 10: Heat pipe based cooling system [116].

Chenlo and Cid [106] described a linear Fresnel lens cooled by water flow through a galvanized steel pipe. The cells are soft soldered to a copper-aluminum-copper sandwich, which is in turn soldered to the rectangular pipe which presents good electrical and thermal models for uniform and nonuniform cell illumination.

Du et al. [117] proposed an experimental analysis of a water cooled concentrated photovoltaic system with the concentration ratio of 8.5. The water cooler was composed of an aluminum plate with two pipes which were attached at the back of the solar module. They showed that increasing the flow rate of water had a relation with increasing the efficiency of the module and CPV systems performed better with cooling systems.

Two different cooling systems were compared by Farahat [118] for the aim of cooling high concentration photovoltaic systems. Water cooling systems and heat pipe techniques were compared and recommended the heat pipe cooling method as the best method for HCPV.

Geng et al. [119] performed both numerical and experimental studies on cooling the high concentration photovoltaic by applying oscillating heat pipes as the cooling system. Their numerical study analyzed the temperature distribution under different heat flux and some other outdoor conditions. Their results demonstrated that using heat pipes was a reliable, simple, uniform, and costless cooling method. Also, oscillating heat pipes need no air fan or pump and have no power consumption which makes them suitable for HCPV systems.

Chong and Tan [120] discussed a study on applying an automotive radiator as the active cooling system of the densearray concentrator photovoltaic system. They employed a computational fluid dynamic (CFD) to perform a flow and heat transfer analysis for the cooling system of the mentioned CPV. For evaluation and feasibility of the study, they set up an experimental procedure with the concentration ratio of 377 suns. They observed that by applying the cooling system when the temperature of the cell reduced from $59.4^{\circ} \mathrm{C}$ to $37.1^{\circ} \mathrm{C}$, the efficiency successfully improved from $22.39 \%$ to $26.86 \%$.

During the past decades, heat sinks became popular devices for cooling processes. Many researchers conducted studies about using heat sink for cooling CPV systems.

Karathanassis et al. [121] conducted a study about optimizing the microchannel, plate-fin heat sink suitable for the cooling of a linear parabolic trough concentrating photovoltaic/thermal (CPVT) system. Their results showed that 


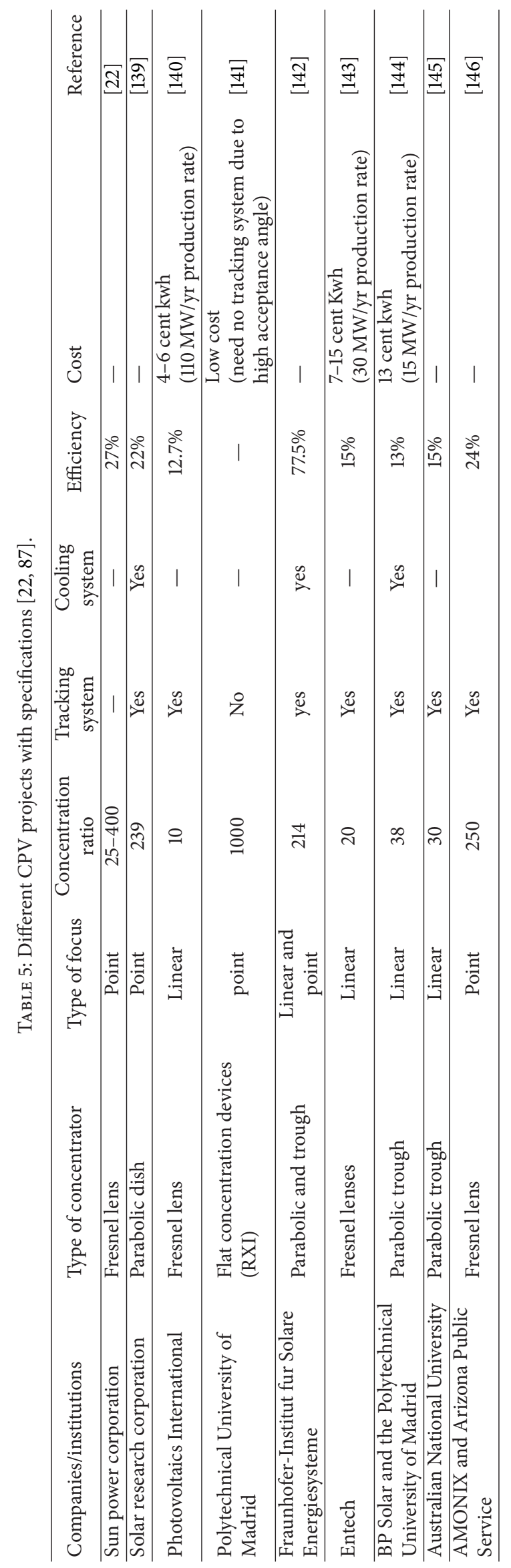


TABLE 6: Comparative analysis of different CPV systems from economic aspects [49].

\begin{tabular}{lcccc}
\hline Primary concentrator & Secondary concentrator & Tracking system & Concentration ratio & $\begin{array}{c}\text { Cost } \\
\$ / \text { Wp }\end{array}$ \\
\hline Point focus Fresnel lens & No & Gimbals & 36 & 1.48 \\
Cylindrical paraboloid & Point-focus CPC & Polar & 65 & 1.78 \\
Linear Fresnel lens & Solid CPC & Gimbals & 37 & 2.02 \\
Curved TIR lens & No & Polar & 28 & 1.97 \\
Curved Fresnel lens & No & Polar & 15 & 2.18 \\
V-trough, screen printed & No & Polar & 2 & 4.31 \\
\hline
\end{tabular}

The costs given in the table are for cells, optical systems, mountings, and trackers only, including construction costs; balance of system costs are omitted as they are similar for all types of collector. The cost in $\$ / \mathrm{Wp}$ is for collectors at operating temperature and, for concentrators, is based on direct beam irradiance of $850 \mathrm{~W} / \mathrm{m}^{2}$; the cost for the flat plate is based on a total irradiance of $1000 \mathrm{~W} / \mathrm{m}^{2}$ [49].

TABLE 7: Fluids compatible with copper and aluminum, based on heat pipe life tests.

\begin{tabular}{lll}
\hline & Copper & Aluminum \\
\hline & & (i) Ammonia \\
& (i) Water & (ii) Acetone \\
Compatible & (ii) Methanol & (iii) Toluene \\
& (iii) Ethanol & (iv) n-Butane \\
& & (v) n-pentane \\
& (vi) n-heptane \\
\hline
\end{tabular}

(i) Water

$\begin{array}{lll}\text { Incompatible } & \text { (i) Ammonia } & \text { (ii) Methanol, other alcohols } \\ \text { (ii) Acetone } & \text { (iii) Benzene (carcinogen) } \\ & \text { (iv) Naphthalene }\end{array}$

microchannel heat sinks are ideal high heat flux dissipation as they achieve thermal resistance values as low as $0.0082 \mathrm{~K} / \mathrm{W}$. Also, their 1-D model could predict the flow and conjugate heat transfer inside a microchannel.

Do et al. [122] proposed a thermal resistance correlation as a design tool of a natural convective heat sink with plate-fins for concentrating photovoltaic (CPV). Different experimental investigations were also done for various heat sink geometries, input powers, and inclination angles. Their correlation could predict the effect of inclination angles and fin spacing. The optimized fin spacing was highly dependent on the inclination angle and temperature difference for specific geometry.

Edenburn did an analysis for a point focus Fresnel lens array under passive cooling system [123]. The cooling device is made up of linear fins on all available heat sink surfaces. The passive heat sink keeps the cell temperature below $150^{\circ} \mathrm{C}$ even on extreme days at a concentration level of about 90 suns.

Natarajan et al. [124] elaborated a numerical investigation of solar temperature of concentrated PV using Fresnel lenses with a concentration ratio of $10 \mathrm{x}$ with and without a passive cooling system. The simulation results showed that a number of four fins of $1 \mathrm{~mm}$ thickness and $5 \mathrm{~mm}$ height were favorable for the mentioned CPV.

By applying water as working fluid, Kumar and Reddy [125] investigated properties of porous disc receivers by different porosities. Empirical correlations were developed to determine the Nusselt number and friction factor for the porous disc receiver. Satyanarayana et al. [126] developed different porous enhanced receiver configurations to increase the heat transfer rate. Drabiniok and Neyer [127] proposed an experimental study about special cooling systems of $\mathrm{PB}$ cells on the basis of a bionic method using a porous compound polymer foil. The foil was laminated directly on silicon substrates providing good thermal contact with the water cooled down by evaporation. A temperature reduction of up to $11.7^{\circ} \mathrm{C}$ was observed and the presented system was capable of self-regulating the water flow and the resulting cooling rate by its direct dependency on environmental conditions like temperature and air velocity.

Sun et al. [128] performed an experimental study about heat dissipation of linear concentrating photovoltaic by applying a direct liquid-immersion cooling method using dimethyl silicon oil. The results showed that the temperature of the cell rose from 0 to 35 increasing linearly with oil temperature. The cooling capacity of the direct liquid-immersion cooling made this method favorable, and the average cell temperature and heat transfer temperature difference could be maintained in the range between $20-31^{\circ} \mathrm{C}$ and $5-16^{\circ} \mathrm{C}$, respectively, at a direct normal irradiance of about $910 \mathrm{~W} / \mathrm{m}^{2}$, $15^{\circ} \mathrm{C}$ silicon oil inlet temperature, and Re numbers varying from 13,602 to 2720 . Finally, they reported no significant efficiency degradation and the electrical performance was considered to be stable after 270 days of silicon oil immersion.

Teo et al. [129] did an experimental study on analyzing the effect of active cooling systems on the efficiency of the PV modules. They applied parallel arrays of ducts with inlet/outlet modified designs for uniform airflow distribution which attached to the back of the module. The efficiency increased from $8-9 \%$ to $12 \%$ and $14 \%$ by using the active cooling system.

Ji et al. [130] performed a numerical and experimental study on using a jet impingement/channel receiver for cooling densely packed PV cells under a paraboloidal dish concentrator. They had shown that the proposed system has the desirable working performance and was of good application potential for the cooling of PV cells exposed to a high heat flux.

Brideau and Collins [131] could increase the heat transfer coefficient between the PV cells and air by using an impinging 
TABLE 8: Main characteristics of different cooling system.

\begin{tabular}{|c|c|c|}
\hline Type & Description & Reference \\
\hline Heat pipe & $\begin{array}{l}\text { (i) Simple } \\
\text { (ii) Reliable } \\
\text { (iii) Uniform } \\
\text { (iv) Costless } \\
\text { (v) Needs no air fan, pump, or energy consumption } \\
\text { (vi) Suitable for HCPV }\end{array}$ & {$[118,119]$} \\
\hline Microchannels & $\begin{array}{l}\text { (i) Low thermal resistance } \\
\text { (ii) Low power requirement } \\
\text { (iii) Ability to remove a large amount of heat in a small area }\end{array}$ & {$[102,147]$} \\
\hline Forced air & $\begin{array}{l}\text { (i) Less efficient than water } \\
\text { (ii) More parasitic power }\end{array}$ & {$[110]$} \\
\hline Porous & High temperature reduction with appropriate attachment & {$[127]$} \\
\hline Impinging jet & Applying the coolant for hybrid system & {$[131]$} \\
\hline
\end{tabular}

jet with the aim of proposing a hybrid PV/T system. Table 8 shows the main description of different cooling systems.

\section{Conclusion}

Environmental issues and energy saving concerns have always been a major global problem. CPV systems are special technology due to their capability of producing electricity with high efficiency. A review of solar photovoltaic concentrators' technologies and their characteristics and properties such as their fundamental functions, efficiencies, concentration ratio, tracking systems, cooling systems, and brief comparison in some parts is presented. Choosing the complete CPV containing the concentrator, tracking system, and cooling system is highly dependent on some limitation factors such as the climate conditions, geographical conditions, budget limits, and space limits. Consequently, for choosing an appropriate CPV system, considerations can be made by using the summarized information provided in Tables $3-8$ by assuming the limitation factors.

Tables 3-6 present the main and specific characteristics of different concentrated photovoltaic systems and Tables 7-8 summarize some factors for choosing the appropriate cooling system.

Through this review paper, we introduced solar concentrated photovoltaic systems in a detailed description in order to provide some main information for scientists and manufactures to improve the CPV technology and to optimize the efficiencies. Finally, it will draw wider interest to the use of concentrated photovoltaic technology.

\section{Conflict of Interests}

The authors declare that there is no conflict of interests regarding the publication of this paper.

\section{Acknowledgment}

The authors gratefully acknowledge Dr. Kiyan Parham, the lecturer of Mechanical Engineering Department in Eastern
Mediterranean University, for his valuable help for searching the literature.

\section{References}

[1] D. Abbott, "Keeping the energy debate clean: how do we supply the world's energy needs?" Proceedings of the IEEE, vol. 98, no. 1, pp. 42-66, 2010.

[2] P. E. Glaser, "Power from the sun: its future," Science, vol. 162, no. 3856, pp. 857-861, 1968.

[3] B. Mendoza, "Total solar irradiance and climate," in Fundamentals of Space Environment Science, V. Jatenco-Pereira, A. C.-L. Chian, J. F. Valdes-Galicia, and M. A. Shea, Eds., pp. 882-890, 2005.

[4] H. Mousazadeh, A. Keyhani, A. Javadi, H. Mobli, K. Abrinia, and A. Sharifi, "A review of principle and sun-tracking methods for maximizing solar systems output," Renewable and Sustainable Energy Reviews, vol. 13, no. 8, pp. 1800-1818, 2009.

[5] A. Lewandowski and D. Simms, "An assessment of linear Fresnel lens concentrators for thermal applications," Energy, vol. 12, no. 3-4, pp. 333-338, 1987.

[6] J. O'Gallagher and R. Winston, "Performance model for twostage optical concentrators for solar thermal applications," Solar Energy, vol. 41, no. 4, pp. 319-325, 1988.

[7] J. Xiao, X. Wei, Z. Lu, W. Yu, and H. Wu, "A review of available methods for surface shape measurement of solar concentrator in solar thermal power applications," Renewable and Sustainable Energy Reviews, vol. 16, no. 5, pp. 2539-2544, 2012.

[8] D. Feuermann, J. M. Gordon, and M. Huleihil, "Light leakage in optical fibers: experimental results, modeling and the consequences for remote lighting and solar concentrator systems," in Nonimaging Optics: Maximum Efficiency Light Transfer VI, R. Winston, Ed., pp. 65-75, August 2001.

[9] A. Garcia-Botella, D. Vazquez, and E. Bcrnabeu, "A new concentrator-collimator lighting system using LED technology," Journal of the Illuminating Engineering Society, vol. 29, no. 2, pp. 135-140, 2000.

[10] A. García-Botella, D. Vázquez, and E. Bernabeu, "Geometric and thermal design for a new concentrator-collimator lighting system based on LED technology," Metrologia, vol. 37, no. 5, pp. 607-610, 2000. 
[11] H. Arashi, D. Cooke, and H. Naito, "Fivefold increase in solar laser output with a nonimaging concentrator," Japanese Journal of Applied Physics 1: Regular Papers \& Short Notes \& Review Papers, vol. 34, no. 9A, pp. 4795-4798, 1995.

[12] H. Arashi, Y. Kaneda, and M. Ishigame, "A solar-pumped laser using a large solar concentrator," in Clean and Safe Energy Forever, T. Horigome, K. Kimura, T. Takakura, T. Nishino, and I. Fujii, Eds., vol. 1-3, pp. 445-449, Pergamon Press, 1990.

[13] S. A. Bakhramov, S. D. Payziyev, S. I. Klychev, A. K. Kasimov, and A. A. Abdurakhmanov, "Laser on the big solar concentrator," in Proceedings of the 2nd International Conference on Advanced Optoelectronics and Lasers (CAOL '05), I. A. Sukhoivanov, Ed., vol. 1, pp. 109-111, September 2005.

[14] V. Krupkin, G. Thompson, A. Yogev, and M. Oron, "Compound parabolical concentrator as pumping device for solid state solar lasers," in 8th Meeting on Optical Engineering in Israel: Optical Engineering and Remote Sensing, M. Oron, I. Shladov, and Y. Weissman, Eds., vol. 1971 of Proceedings of SPIE, pp. 400-407, December 1992.

[15] M. Lando, J. Kagan, and B. Linyekin, "38-watt Nd:YAG laser pumped by a $6.85 \mathrm{~m}^{2}$ target-aligned solar concentrator," in Electro-Optics and Microelectronics, R. Lavi and E. Azoulay, Eds., pp. 33-36, 2000.

[16] W. Villasmil and A. Steinfeld, "Hydrogen production by hydrogen sulfide splitting using concentrated solar energythermodynamics and economic evaluation," Energy Conversion and Management, vol. 51, no. 11, pp. 2353-2361, 2010.

[17] A. Z'Graggen, P. Haueter, G. Maag, M. Romero, and A. Steinfeld, "Hydrogen production by steam-gasification of carbonaceous materials using concentrated solar energy-IV. Reactor experimentation with vacuum residue," International Journal of Hydrogen Energy, vol. 33, no. 2, pp. 679-684, 2008.

[18] A. Z'Graggen, P. Haueter, G. Maag, A. Vidal, M. Romero, and A. Steinfeld, "Hydrogen production by steam-gasification of petroleum coke using concentrated solar power-III. Reactor experimentation with slurry feeding," International Journal of Hydrogen Energy, vol. 32, no. 8, pp. 992-996, 2007.

[19] B. Parida, S. Iniyan, and R. Goic, "A review of solar photovoltaic technologies," Renewable and Sustainable Energy Reviews, vol. 15, no. 3, pp. 1625-1636, 2011.

[20] R. McConnell, S. Kurtz, and M. Symko-Davies, "Concentrator photovoltaic technologies," Refocus, vol. 6, no. 4, pp. 35-39, 2005.

[21] A. Luque and V. Andreev, Concentrator Photovoltaics, Springer, Heidelberg, Germany, 2007.

[22] R. M. Swanson, "The promise of concentrators," Progress in Photovoltaics: Research and Applications, vol. 8, no. 1, pp. 93-111, 2000.

[23] V. Andreev, V. D. Rumyantsev, and V. A. Grilikhes, Photovoltaic Conversion of Concentrated Sunlight, John Wiley \& Sons, Chichester, UK, 1997.

[24] P. Pérez-Higueras, E. Muñoz, G. Almonacid, and P. G. Vidal, "High Concentrator PhotoVoltaics efficiencies: present status and forecast," Renewable and Sustainable Energy Reviews, vol. 15, no. 4, pp. 1810-1815, 2011.

[25] S. J. Gallagher, B. Norton, and P. C. Eames, "Quantum dot solar concentrators: electrical conversion efficiencies and comparative concentrating factors of fabricated devices," Solar Energy, vol. 81, no. 6, pp. 813-821, 2007.

[26] J. Lushetsky, Accelerating Innovation in Solar Technologies Overview of the DOE Solar Energy Technology Program, US
Department of Energy: Solar Energy Technologies Program, 2008.

[27] B. A. Butler, E. E. van Dyk, F. J. Vorster, W. Okullo, M. K. Munji, and P. Booysen, "Characterization of a low concentrator photovoltaics module," Physica B: Condensed Matter, vol. 407, no. 10, pp. 1501-1504, 2012.

[28] R. Winston, J. J. O'Gallagher, and R. Gee, "Nonimaging solar concentrator with uniform irradiance," in Nonimaging Optics and Efficient Illumination Systems, R. Winston and R. J. Koshel, Eds., pp. 237-239, August 2004.

[29] A. Garcia-Botella, A. A. Fernandez-Balbuena, D. Vázquez, and E. Bernabeu, "Ideal 3D asymmetric concentrator," Solar Energy, vol. 83, no. 1, pp. 113-117, 2009.

[30] W. T. Xie, Y. J. Dai, R. Z. Wang, and K. Sumathy, "Concentrated solar energy applications using Fresnel lenses: a review," Renewable and Sustainable Energy Reviews, vol. 15, no. 6, pp. 25882606, 2011.

[31] R. Leutz and A. Suzuki, Nonimaging Fresnel Lenses: Design and Performance of Solar Concentrators, Springer, Berlin, Germany, 2001.

[32] R. Leutz, A. Suzuki, A. Akisawa, and T. Kashiwagi, "Developments and designs of solar engineering Fresnel lenses," in Proceedings of the Symposium on Energy Engineering, Hong Kong, 2000.

[33] C. Sierra and A. J. Vázquez, "High solar energy concentration with a Fresnel lens," Journal of Materials Science, vol. 40, no. 6, pp. 1339-1343, 2005.

[34] D. C. Miller and S. R. Kurtz, "Durability of Fresnel lenses: a review specific to the concentrating photovoltaic application," Solar Energy Materials and Solar Cells, vol. 95, no. 8, pp. 20372068, 2011.

[35] E. Lorenzo and A. Luque, "Fresnel lens analysis for solar energy applications," Applied Optics, vol. 20, no. 17, pp. 2941-2945, 1981.

[36] M. M. Valmiki, P. Li, J. Heyer et al., "A novel application of a Fresnel lens for a solar stove and solar heating," Renewable Energy, vol. 36, no. 5, pp. 1614-1620, 2011.

[37] J. M. Monteagudo and A. Durán, "Fresnel lens to concentrate solar energy for the photocatalytic decoloration and mineralization of orange II in aqueous solution," Chemosphere, vol. 65, no. 7, pp. 1242-1248, 2006.

[38] Y. Chen, "The continuous production of fresnel lens and a discussion on its application in solar building Chen Yike," in Proceedings of ISES World Congress 2007, D. Y. Goswami and Y. W. Zhao, Eds., vol. 1-5, pp. 323-326, 2007.

[39] T. Ohkubo, T. Yabe, K. Yoshida et al., "Solar-pumped $80 \mathrm{~W}$ laser irradiated by a Fresnel lens," Optics Letters, vol. 34, no. 2, pp. 175-177, 2009.

[40] T. Yabe, B. Bagheri, T. Ohkubo et al., "100 W-class solar pumped laser for sustainable magnesium-hydrogen energy cycle," Journal of Applied Physics, vol. 104, no. 8, Article ID 083104, 2008.

[41] T. Yabe, T. Ohkubo, S. Uchida et al., "High-efficiency and economical solar-energy-pumped laser with Fresnel lens and chromium codoped laser medium," Applied Physics Letters, vol. 90, no. 26, Article ID 261120, 2007.

[42] Y. Tripanagnostopoulos, C. Siabekou, and J. K. Tonui, "The Fresnel lens concept for solar control of buildings," Solar Energy, vol. 81, no. 5, pp. 661-675, 2007.

[43] A. Tsangrassoulis, L. Doulos, M. Santamouris et al., "On the energy efficiency of a prototype hybrid daylighting system," Solar Energy, vol. 79, no. 1, pp. 56-64, 2005. 
[44] C. Sierra, E. Michie, and A. J. Vázquez, "Production improvement of NiAl coatings achieved by self-propagating hightemperature synthesis with concentrated solar energy," Revista de Metalurgia, pp. 469-474, 2005.

[45] C. Sierra and A. J. Vázquez, "NiAl coatings on carbon steel by self-propagating high-temperature synthesis assisted with concentrated solar energy: mass influence on adherence and porosity," Solar Energy Materials and Solar Cells, vol. 86, no. 1, pp. 33-42, 2005.

[46] C. Sierra and A. J. Vázquez, "NiAl coating on carbon steel with an intermediate Ni gradient layer," Surface \& Coatings Technology, vol. 200, no. 14-15, pp. 4383-4388, 2006.

[47] Y. Nakata, N. Shibuya, T. Kobe, K. Okamoto, A. Suzuki, and T. Tsuji, "Performance of circular Fresnel lens photovoltaic concentrator," Japanese Journal of Applied Physics, vol. 19, pp. 75-78, 1980.

[48] S. Harmon, "Solar-optical analyses of a mass-produced plastic circular Fresnel lens," Solar Energy, vol. 19, no. 1, pp. 105-108, 1977.

[49] G. R. Whitfield, R. W. Bentley, C. K. Weatherby et al., "The development and testing of small concentrating PV systems," Solar Energy, vol. 67, no. 1-3, pp. 23-34, 1999.

[50] F. Franc, V. Jirka, M. Malý, and B. Nábělek, "Concentrating collectors with flat linear fresnel lenses," Solar and Wind Technology, vol. 3, no. 2, pp. 77-84, 1986.

[51] D. Gerion, F. Pinaud, S. C. Williams et al., "Synthesis and properties of biocompatible water-soluble silica-coated CdSe/ZnS semiconductor quantum dots," Journal of Physical Chemistry B, vol. 105, no. 37, pp. 8861-8871, 2001.

[52] O. I. Mićić, H. M. Cheong, H. Fu et al., "Size-dependent spectroscopy of InP quantum dots," Journal of Physical Chemistry B, vol. 101, no. 25, pp. 4904-4912, 1997.

[53] R. Reisfeld and C. K. Jorgensen, "Luminescent solar concentrators for energy conversion," Structure and Bonding, vol. 49, pp. 1-36, 1982.

[54] K. Barnham, J. L. Marques, J. Hassard, and P. O'Brien, "Quantum-dot concentrator and thermodynamic model for the global redshift," Applied Physics Letters, vol. 76, no. 9, pp. 1197$1199,2000$.

[55] V. Wittwer, K. Heidler, A. Zastrow, and A. Goetzberger, “Theory of fluorescent planar concentrators and experimental results," Journal of Luminescence, vol. 24-25, no. 2, pp. 873-876, 1981.

[56] A. Goetzberger, W. Stahl, and V. Wittwer, "Physical limitations of the concentration of direct and diffuse radiation," in Proceedings of the 6th European Photovoltaic Solar Energy Conference, Reidel, Dordrecht, The Netherlands, 1985.

[57] A. P. Alivisatos, "Perspectives on the physical chemistry of semiconductor nanocrystals," The Journal of Physical Chemistry, vol. 100, no. 31, pp. 13226-13239, 1996.

[58] A. Schüler, M. Python, M. V. del Olmo, and E. de Chambrier, "Quantum dot containing nanocomposite thin films for photoluminescent solar concentrators," Solar Energy, vol. 81, no. 9, pp. 1159-1165, 2007.

[59] K. R. Kumar and K. S. Reddy, "Effect of porous disc receiver configurations on performance of solar parabolic trough concentrator," Heat and Mass Transfer, vol. 48, no. 3, pp. 555-571, 2012.

[60] J. A. Clark, "An analysis of the technical and economic performance of a parabolic trough concentrator for solar industrial process heat application," International Journal of Heat and Mass Transfer, vol. 25, no. 9, pp. 1427-1438, 1982.
[61] K.-J. Riffelmann, A. Neumann, and S. Ulmer, "Performance enhancement of parabolic trough collectors by solar flux measurement in the focal region," Solar Energy, vol. 80, no. 10, pp. 1303-1313, 2006.

[62] S. A. Omer and D. G. Infield, "Design and thermal analysis of a two stage solar concentrator for combined heat and thermoelectric power generation," Energy Conversion and Management, vol. 41, no. 7, pp. 737-756, 2000.

[63] M. A. Al-Nimr and M. K. Alkam, "A modified tubeless solar collector partially filled with porous substrate," Renewable Energy, vol. 13, no. 2, pp. 165-173, 1998.

[64] K. R. Kumar and K. S. Reddy, "Thermal analysis of solar parabolic trough with porous disc receiver," Applied Energy, vol. 86, no. 9, pp. 1804-1812, 2009.

[65] S. D. Odeh, G. L. Morrison, and M. Behnia, "Modelling of parabolic trough direct steam generation solar collectors," Solar Energy, vol. 62, no. 6, pp. 395-406, 1998.

[66] K. S. Reddy, K. R. Kumar, and G. V. Satyanarayana, "Numerical investigation of energy-efficient receiver for solar parabolic trough concentrator," Heat Transfer Engineering, vol. 29, no. 11, pp. 961-972, 2008.

[67] K. S. Reddy and G. V. Satyanarayana, "Numerical study of porous finned receiver for solar parabolic trough concentrator," Engineering Applications of Computational Fluid Mechanics, vol. 2, no. 2, pp. 172-184, 2008.

[68] Q.-C. Zhang, K. Zhao, B.-C. Zhang et al., "New cermet solar coatings for solar thermal electricity applications," Solar Energy, vol. 64, no. 1-3, pp. 109-114, 1998.

[69] A. Rabl, Active Solar Collectors and Their Applications, Oxford University Press, New York, NY, USA, 1985.

[70] F. Kreith and J. E. Kreider, Principles of Solar Engineering, McGraw-Hill, New York, NY, USA, 1978.

[71] J. A. Duffie and W. A. Beckman, Solar Engineering of Thermal Processes, John Wiley \& Sons, Hoboken, NJ, USA, 2006.

[72] F. Kreith and J. E. Kreider, Principles of Solar Engineering, Hemisphere Publishing Corporation, Washington, DC, USA, 1978.

[73] A. Suzuki and S. Kobayashi, "Yearly distributed insolation model and optimum design of a two dimensional compound parabolic concentrator," Solar Energy, vol. 54, no. 5, pp. 327-331, 1995.

[74] S. Senthilkumar, K. Perumal, and P. S. S. Srinivasan, "Construction and performance analysis of a three dimensional compound parabolic concentrator for a spherical absorber," Journal of Scientific and Industrial Research, vol. 66, no. 7, pp. 558-564, 2007.

[75] N. Yehezkel, J. Appelbaum, A. Yogev, and M. Oron, "Losses in a three-dimensional compound parabolic concentrator as a second stage of a solar concentrator," Solar Energy, vol. 51, no. 1, pp. 45-51, 1993.

[76] A.-J. N. Khalifa and S. S. Al-Mutawalli, "Effect of two-axis sun tracking on the performance of compound parabolic concentrators," Energy Conversion and Management, vol. 39, no. 10, pp. 1073-1079, 1998.

[77] T. K. Mallick, P. C. Eames, T. J. Hyde, and B. Norton, “The design and experimental characterisation of an asymmetric compound parabolic photovoltaic concentrator for building façade integration in the UK," Solar Energy, vol. 77, no. 3, pp. 319-327, 2004.

[78] X. Ning, R. Winston, and J. O'Gallagher, "Dielectric totally internally reflecting concentrators," Applied Optics, vol. 26, no. 2, pp. 300-305, 1987. 
[79] X. H. Ning, "Application of nonimaging optical concentrators to infrared energy detection," in Nonimaging Optics: Maximum Efficiency Light Transfer, vol. 1528 of Proceedings of SPIE, p. 88, 1991.

[80] R. Ramirez-Iniguez and R. Green, "Elliptical and parabolic totally internally reflecting optical antennas for wireless infrared communications," in Proceedings of the IrDA/IEE/IEEE Conference on Optical Wireless, Warwick University, 2003.

[81] R. Ramirez-Iniguez and R. J. Green, "Optical antenna design for indoor optical wireless communication systems," International Journal of Communication Systems, vol. 18, no. 3, pp. 229-245, 2005.

[82] X. H. Ning, J. O'Gallagher, and R. Winston, "Optics of twostage photovoltaic concentrators with dielectric second stages," Applied Optics, vol. 26, no. 7, pp. 1207-1212, 1987.

[83] F. Muhammad-Sukki, R. Ramirez-Iniguez, S. G. McMeekin, B. G. Stewart, and B. Clive, "Optimised dielectric totally internally reflecting concentrator for the solar photonic optoelectronic transformer system: maximum concentration method," in Knowledge-Based and Intelligent Information and Engineering Systems, R. Setchi, I. Jordanov, R. J. Howlett, and L. C. Jain, Eds., vol. 6279 of Lecture Notes in Computer Science, pp. 633641, Springer, Berlin, Germany, 2010.

[84] M. F. Piszczor and R. P. Macosko, "A high-efficiency refractive secondary solar concentrator for high temperature solar thermal applications," Technical Memorandum, NASA, 2000.

[85] F. Muhammad-Sukki, S. H. Abu-Bakar, R. Ramirez-Iniguez et al., "Mirror symmetrical dielectric totally internally reflecting concentrator for building integrated photovoltaic systems," Applied Energy, vol. 113, pp. 32-40, 2014.

[86] I. M. S. Ali, T. K. Mallick, P. A. Kew, T. S. O’Donovan, and K. S. Reddy, "Optical performance evaluation of a 2-D and 3-D novel hyperboloid solar concentrator," in Proceedings of the 11th World Renewable Energy Congress, Abu Dhabi, UAE, 2010.

[87] F. Muhammad-Sukki, R. Ramirez-Iniguez, S. G. McMeekin, B. G. Stewart, and B. Clive, "Solar concentrators," International Journal of Applied Sciences, vol. 1, no. 1, pp. 1-15, 2010.

[88] N. Sellami, T. K. Mallick, and D. A. McNeil, "Optical characterisation of 3-D static solar concentrator," Energy Conversion and Management, vol. 64, pp. 579-586, 2012.

[89] A. García-Botella, A. Á. Fernández-Balbuena, D. Vázquez, E. Bernabeu, and A. González-Cano, "Hyperparabolic concentrators," Applied Optics, vol. 48, no. 4, pp. 712-715, 2009.

[90] J. M. Gordon, "Complementary construction of ideal nonimaging concentrators and its applications," Applied Optics, vol. 35, no. 28, pp. 5677-5682, 1996.

[91] C.-F. Chen, C.-H. Lin, H.-T. Jan, and Y.-L. Yang, "Design of a solar concentrator combining paraboloidal and hyperbolic mirrors using ray tracing method," Optics Communications, vol. 282, no. 3, pp. 360-366, 2009.

[92] I. M. Saleh Ali, T. Srihari Vikram, T. S. O’Donovan, K. S. Reddy, and T. K. Mallick, "Design and experimental analysis of a static 3-D elliptical hyperboloid concentrator for process heat applications," Solar Energy, vol. 102, pp. 257-266, 2014.

[93] J. C. Minano, J. C. Gonzalez, and I. Zanesco, "Flat high concentration devices," in Proceedings of the 24th IEEE Photovoltaic Specialists Conference, vol. 1-2, pp. 1123-1126, IEEE, New York, NY, USA, December 1994.

[94] R. Winston, J. C. Minano, and P. Benitez, Nonimaging Optics, Elsevier Academic Press, San Diego, Calif, USA, 2005.
[95] J. C. Minano, J. C. Gonzalez, and P. Benitez, "A high-gain, compact, nonimaging concentrator: RXI," Applied Optics, vol. 34, no. 34, pp. 7850-7856, 1995.

[96] J. C. Minano, P. Benitez, and J. C. Gonzalez, "RX: a nonimaging concentrator," Applied Optics, vol. 34, no. 13, pp. 2226-2235, 1995.

[97] P. Benitez and J. C. Minano, "Analysis of the image formation capability of RX concentrators," in Nonimaging Optics: Maximum Efficiency Light Transfer III, R. Winston, Ed., vol. 2538, pp. 73-84, 1995.

[98] J. C. Minano, J. C. Gonzalez, and P. Benitez, "New nonimaging designs: the RX and the RXI concentrators," in Nonimaging Optics: Maximum-Efficiency Light Transfer II, R. Winston and R. L. Holman, Eds., vol. 2016 of Proceedings of SPIE, pp. 120 127, 1993.

[99] I. Peterina, A. B. Cueli, J. Díaz, J. Moracho, and A. R. Lagunas, "CENER experience testing CPV modules," Energetica International, no. 123, 2012.

[100] V. L. Dalal and A. R. Moore, "Design considerations for highintensity solar cell," Journal of Applied Physics, vol. 48, no. 3, p. 8, 1977.

[101] D. J. Mbewe, H. C. Card, and D. C. Card, "A model of silicon solar cells for concentrator photovoltaic and photovoltaic/thermal system design," Solar Energy, vol. 35, no. 3, pp. 247-258, 1985.

[102] A. Royne, C. J. Dey, and D. R. Mills, "Cooling of photovoltaic cells under concentrated illumination: a critical review," Solar Energy Materials and Solar Cells, vol. 86, no. 4, pp. 451-483, 2005.

[103] G. Sala, "Cooling of solar cells," in Cells and Optics for Photovoltaic Concentration, A. Hilger, Ed., pp. 239-267, Adam Hilger, Bristol, UK, 1989.

[104] I. Anton, G. Sala, and D. Pachon, "Correction of the Voc vs. temperature dependence under non-uniform concentrated illumination," in Proceedings of the 17th European Photovoltaic Solar Energy Conference, pp. 156-159, Munich, Germany, 2001.

[105] A. Cheknane, B. Benyoucef, and A. Chaker, "Performance of concentrator solar cells with passive cooling," Semiconductor Science and Technology, vol. 21, no. 2, pp. 144-147, 2006.

[106] F. Chenlo and M. Cid, "A linear concentrator photovoltaic module: analysis of non-uniform illumination and temperature effects on efficiency," Solar Cells, vol. 20, no. 1, pp. 27-39, 1987.

[107] A. Luque, G. Sala, and J. C. Arboiro, "Electric and thermal model for non-uniformly illuminated concentration cells," Solar Energy Materials and Solar Cells, vol. 51, no. 3-4, pp. 269-290, 1998.

[108] R. K. Mathur, D. R. Mehrotra, S. Mittal, and S. R. Dhariwal, "Thermal non-uniformities in concentrator solar cells," Solar Cells, vol. 11, no. 2, pp. 175-188, 1984.

[109] R. W. Sanderson, D. T. O'Donnell, and C. E. Backus, "The effects of nonuniform illumination and temperature profiles on silicon solar cells under concentrated sunlight," in Proceedings of the 14th IEEE Photovoltaic Specialists Conference (PVSC '80), pp. 431-436, January 1980.

[110] A. D. Kraus and A. Bar-Cohen, Design and Analysis of Heat Sinks, John Wiley \& Sons, New York, NY, USA, 1st edition, 1995.

[111] W. G. Anderson, P. M. Dussinger, D. B. Sarraf, and S. Tamanna, "Heat pipe cooling of concentrating photovoltaic cells," in Proceedings of the 33rd IEEE Photovoltaic Specialists Conference (PVSC '08), May 2008. 
[112] P. D. Dunn and D. A. Reay, Heat Pipes, Elsevier Science, Tarrytown, NY, USA, 4th edition, 1994.

[113] W. G. Anderson, "Intermediate temperature fluids for heat pipes and LHPs," in Proceedings of the 5th International Energy Conversion Engineering Conference (IECEC '07), AIAA, St. Louis, Mo, USA, 2007.

[114] A. Akbarzadeh and T. Wadowski, "Heat pipe-based cooling systems for photovoltaic cells under concentrated solar radiation," Applied Thermal Engineering, vol. 16, no. 1, pp. 81-87, 1996.

[115] W. E. Horne, “Solar energy system," US patent no. 5269851, 1993.

[116] R. F. Russell, "Uniform temperature heat pipe and method of using the same," US patent no. 4320246, 1982.

[117] B. Du, E. Hu, and M. Kolhe, "Performance analysis of water cooled concentrated photovoltaic (CPV) system," Renewable and Sustainable Energy Reviews, vol. 16, no. 9, pp. 6732-6736, 2012.

[118] M. A. Farahat, "Improvement the thermal electric performance of a photovoltaic cells by cooling and concentration techniques," in Proceedings of the 39th International Universities Power Engineering Conference (UPEC '04), pp. 623-628, September 2004.

[119] W.-G. Geng, L. Gao, M. Shao, and X.-Y. Li, "Numerical and experimental study on cooling high-concentration photovoltaic cells with oscillating heat pipe," International Journal of LowCarbon Technologies, vol. 7, no. 3, pp. 168-173, 2012.

[120] K.-K. Chong and W.-C. Tan, "Study of automotive radiator cooling system for dense-array concentration photovoltaic system," Solar Energy, vol. 86, no. 9, pp. 2632-2643, 2012.

[121] I. K. Karathanassis, E. Papanicolaou, V. Belessiotis, and G. C. Bergeles, "Multi-objective design optimization of a micro heat sink for Concentrating Photovoltaic/Thermal (CPVT) systems using a genetic algorithm," Applied Thermal Engineering, vol. 59, no. 1-2, pp. 733-744, 2013.

[122] K. H. Do, T. H. Kim, Y.-S. Han, B.-I. Choi, and M.-B. Kim, "General correlation of a natural convective heat sink with plate-fins for high concentrating photovoltaic module cooling," Solar Energy, vol. 86, no. 9, pp. 2725-2734, 2012.

[123] M. W. Edenburn, "Active and passive cooling for concentrating photovoltaic arrays," in Proceedings of the 14th Photovoltaic Specialists Conference, pp. 771-776, San Diego, Calif, USA, January 1980.

[124] S. K. Natarajan, T. K. Mallick, M. Katz, and S. Weingaertner, "Numerical investigations of solar cell temperature for photovoltaic concentrator system with and without passive cooling arrangements," International Journal of Thermal Sciences, vol. 50, no. 12, pp. 2514-2521, 2011.

[125] K. R. Kumar and K. S. Reddy, "Investigation of heat transfer characteristics of line focus receiver with porous disc inserts for solar parabolic trough concentrator," in Proceedings of the 20th National and 9th International ISHMT-ASME Heat and Mass Transfer Conference, Mumbai, India, 2010.

[126] G. V. Satyanarayana, K. R. Kumar, and K. S. Reddy, "Numerical study of porous enhanced receiver for solar parabolic trough collector," in Proceedings of the 3rd International Conference on Solar Radiation and Day Lighting, New Delhi, India, 2007.

[127] E. Drabiniok and A. Neyer, "Bionic micro porous evaporation foil for photovoltaic cell cooling," Microelectronic Engineering, vol. 119, pp. 65-69, 2014.

[128] Y. Sun, Y. Wang, L. Zhu, B. Yin, H. Xiang, and Q. Huang, "Direct liquid-immersion cooling of concentrator silicon solar cells in a linear concentrating photovoltaic receiver," Energy, vol. 65, pp. 264-271, 2014.
[129] H. G. Teo, P. S. Lee, and M. N. A. Hawlader, "An active cooling system for photovoltaic modules," Applied Energy, vol. 90, no. 1, pp. 309-315, 2012.

[130] J. Ji, Y. Wang, T.-T. Chow, H. Chen, and G. Pei, "A jet impingement/channel receiver for cooling densely packed photovoltaic cells under a paraboloidal dish solar concentrator," Heat Transfer Research, vol. 43, no. 8, pp. 767-778, 2012.

[131] S. A. Brideau and M. R. Collins, "Development and validation of a hybrid PV/Thermal air based collector model with impinging jets," Solar Energy, vol. 102, pp. 234-246, 2014.

[132] C. A. Mgbemene, J. Duffy, H. Sun, and S. O. Onyegegbu, "Electricity generation from a compound parabolic concentrator coupled to a thermoelectric module," Journal of Solar Energy Engineering, vol. 132, no. 3, 2010.

[133] P. D. Menghani, R. R. Udawant, A. M. Funde, and S. V. Dingare, "Low pressure steam generation by solar energy withfresnel lens: a review," IOSR Journal of Mechanical and Civil Engineering, vol. 5, pp. 60-63, 2013.

[134] O. E. Miller, J. H. Mcleod, and W. T. Sherwood, "Thin sheet plastic Fresnel lenses of high aperture," Journal of the Optical Society of America, vol. 41, no. 11, p. 8, 1951.

[135] S. Malato, J. Blanco, A. Vidal, and C. Richter, "Photocatalysis with solar energy at a pilot-plant scale: an overview," Applied Catalysis B: Environmental, vol. 37, no. 1, pp. 1-15, 2002.

[136] G.-L. Dai, X.-L. Xia, C. Sun, and H.-C. Zhang, "Numerical investigation of the solar concentrating characteristics of $3 \mathrm{D}$ CPC and CPC-DC," Solar Energy, vol. 85, no. 11, pp. 2833-2842, 2011.

[137] E. Hossain, R. Muhida, A. F. Dzulkipli, and K. A. A. Rahman, "Solar cell efficiency improvement using compound parabolic concentrator and an implementation of sun tracking system," in Proceedings of the 11th International Conference on Computer and Information Technology (ICCIT '08), vol. 1-2, pp. 723-728, December 2008.

[138] A. Terao, W. P. Mulligan, S. G. Daroczi et al., "A mirror-less design for micro-concentrator modules," in Proceedings of the 28th IEEE Photovoltaic Specialists Conference, pp. 1416-1419, 2000.

[139] J. B. Lasich, A. Cleeve, N. Kaila et al., "Close-packed cell arrays for dish concentrators," in Proceedings of the 24th IEEE Photovoltaic Specialists Conference, pp. 1938-1941, December 1994.

[140] N. Kaminar, J. McEntree, P. Stark, and D. Curchod, "SEA 10X concentrator development progress," in Proceedings of the 22nd IEEE Photovoltaic Specialists Conference, pp. 529-532, October 1991.

[141] J. L. Alvarez, M. Hernandez, P. Benitez, and J. C. Minano, "Experimental measurements of RXI concentrators for photovoltaic applications," in Proceedings of the $2 n d$ World Conference and Exhibition on Photovoltaic Solar Energy Conversion, Vienna, Austria, 1998.

[142] M. Brunotte, A. Goetzberger, and U. Blieske, "Two-stage concentrator permitting concentration factors up to $300 \mathrm{X}$ with oneaxis tracking," Solar Energy, vol. 56, no. 3, pp. 285-300, 1996.

[143] M. J. O'Neill and A. J. McDanal, "Fourth-generation concentrator system: from the lab to the factory to the field," in Proceedings of the 24th IEEE Photovoltaic Specialists Conference, pp. 816-819, December 1994.

[144] G. Sala, J. C. Arboiro, A. Luque et al., “ 480 kW peak EUCLIDES concentrator power plant using parabolic troughs," in Proceedings of the 2nd World Conference and Exhibition on Photovoltaic Solar Energy Conversion, Vienna, Austria, 1998. 
[145] A. W. Blakers and J. Smeltink, "The ANU PV/trough concentrator system," in Proceedings of the 2nd World Conference on Photovoltaic Solar Energy Conversion, Vienna, Austria, 1998.

[146] V. Garboushian, S. Yoon, G. Turner, A. Gunn, and D. Fair, "A novel high-concentration PV technology for cost competitive utility bulk power generation," in Proceedings of the 1st World Conference on Photovoltaic Energy Conversion, pp. 1060-1063, Waikoloa, Hawaii, USA, December 1994.

[147] D. B. Tuckerman and R. F. W. Pease, "High-performance heat sinking for VLSI," Electron Device Letters, vol. 2, no. 5, pp. 126129, 1981. 

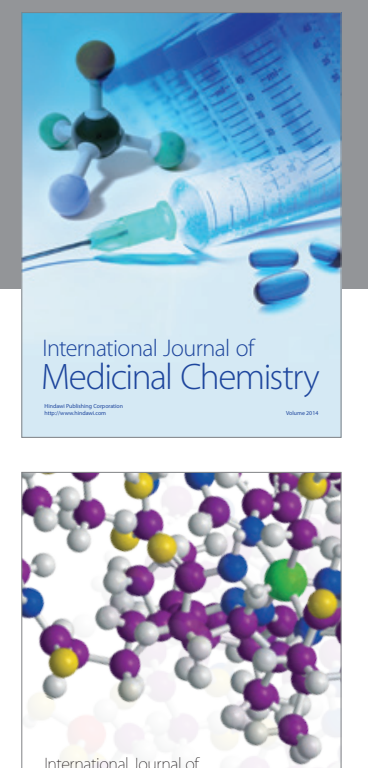

\section{Carbohydrate} Chemistry

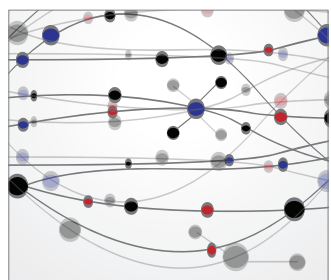

The Scientific World Journal
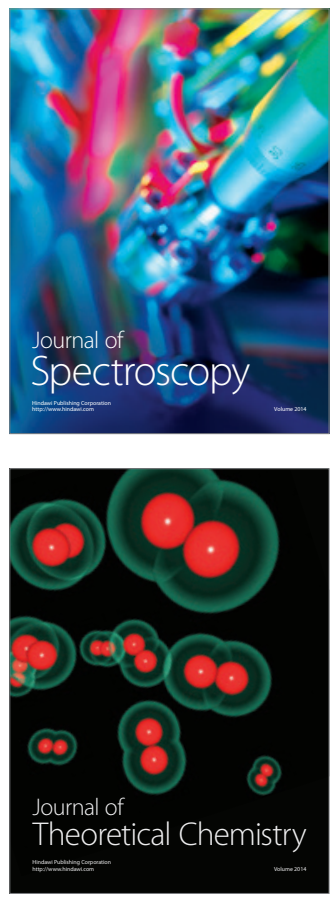
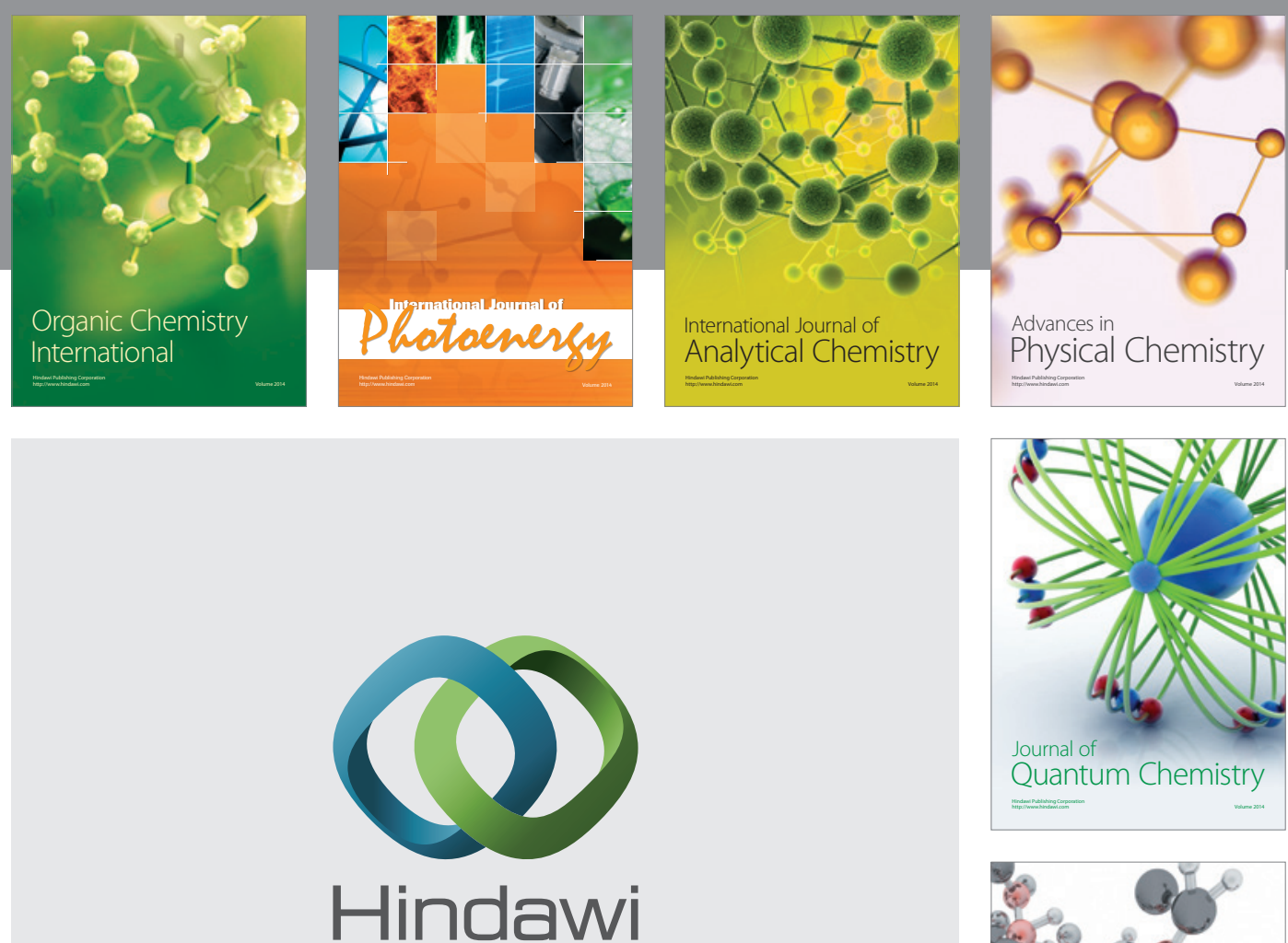

Submit your manuscripts at

http://www.hindawi.com

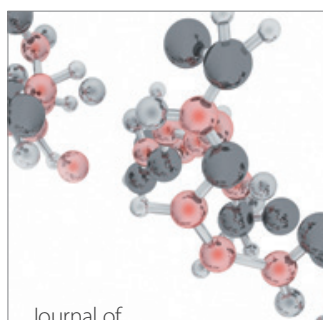

Analytical Methods

in Chemistry

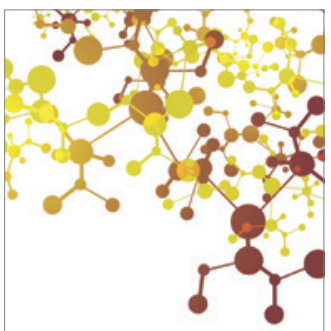

Journal of

Applied Chemistry

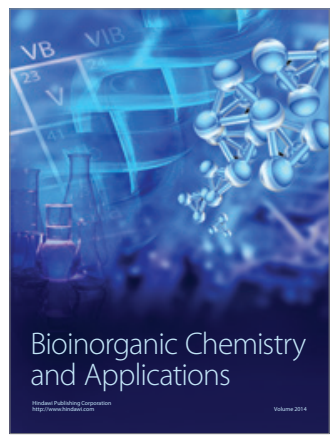

Inorganic Chemistry
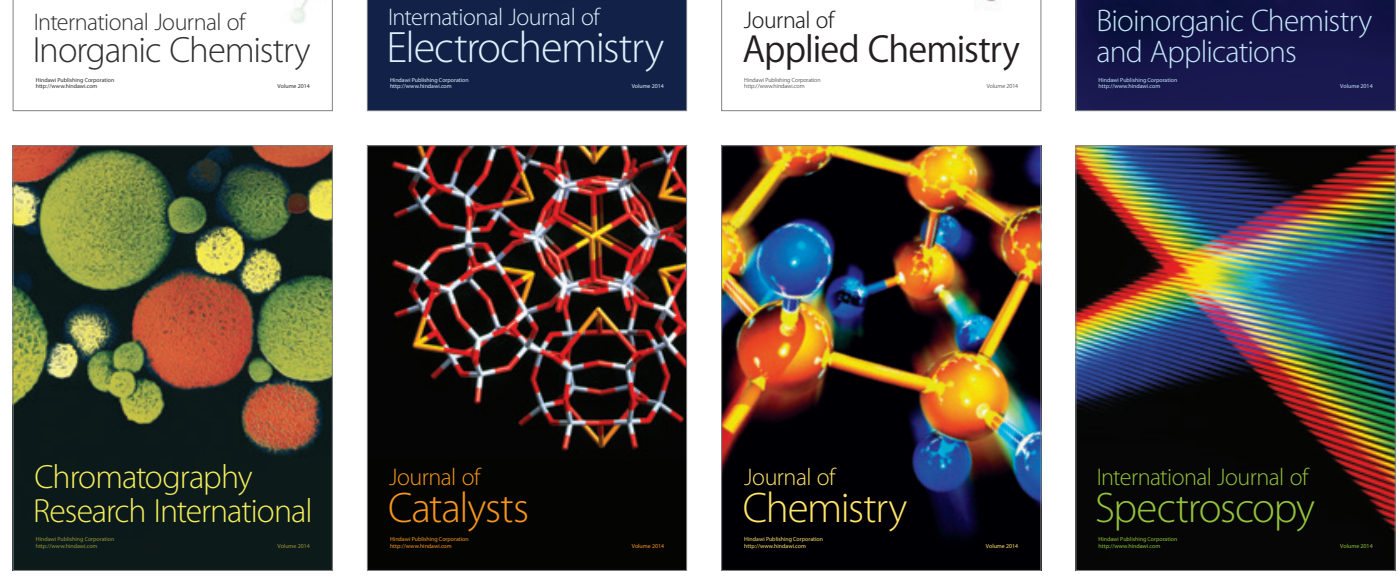